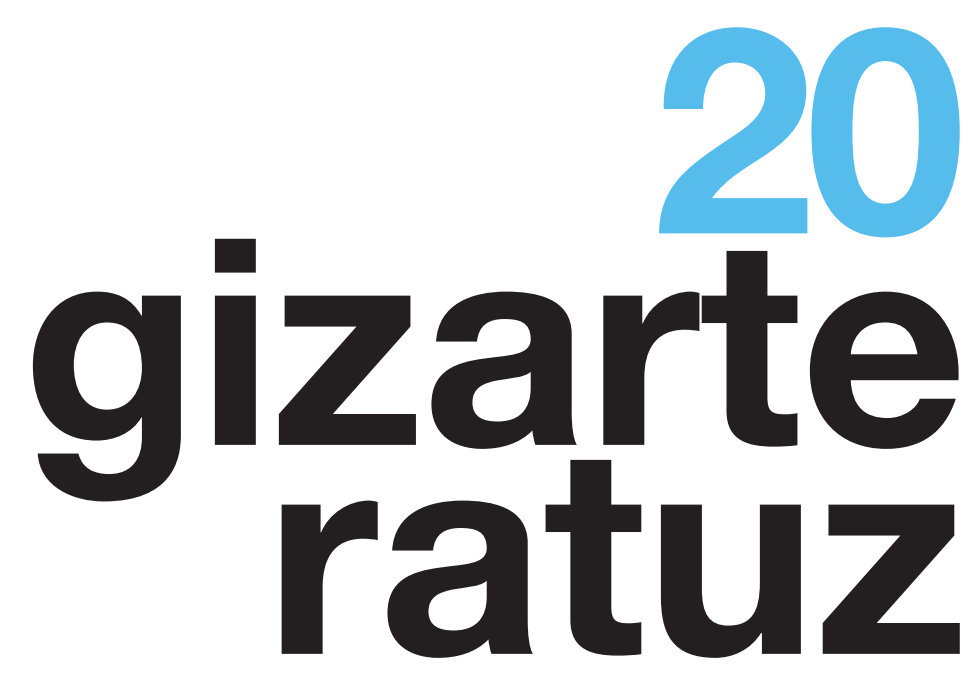

Urria 2011 Octubre

Gizarte Gaiei buruzko Dokumentazio Aldizkaria

Boletín Documental sobre Asuntos Sociales

El Gobierno Vasco organiza unas jornadas para debatir sobre el modelo de inclusión activa en la CAPV

8

Javier Ruiz: 'Proponemos un modelo de inclusión activa que contempla la mejora de

la empleabilidad como un derecho social básico’

Zer da bizimodu independentea? Eskubidea versus errealitatea, Gipuzkoako esperientzia

El impacto de la crisis económica sobre la cohesión social

¿Por qué muchos menores permanecen largos intervalos de su vida en acogimiento residencial? 

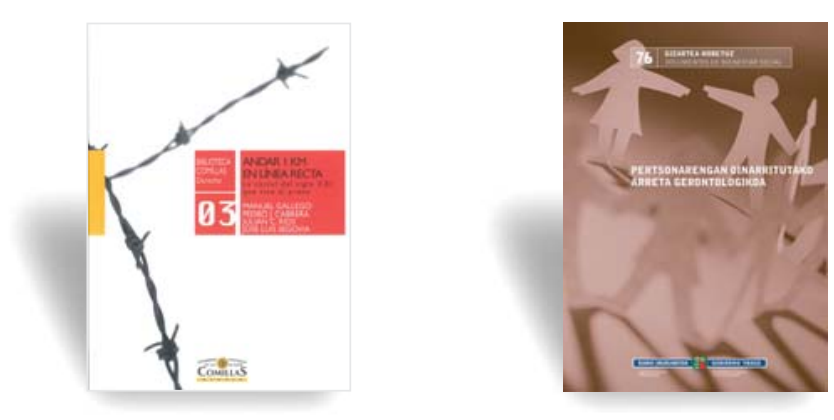

\section{nove berriak}

SiiS-eko Liburutegian kontsultatu daitezke aldizkari honetan agertzen diren dokumentu guztiak. Dokumentu horien kopia edo mailegua eskatu daiteke telefonoz, faxez edo posta elektronikoz,

Buletinaren bertsio elektronikoa irakurtzen ari bazara, sakatu irakurtzen ari bazara, sakatu eging zaizu dum egingo zaizu dokumentazioko datu-basearen biblografia-fitxa. Aldizkaria eskutan izanez gero, erreferentzia-zenbaki hori sartuz, kontsulta dozakezu <uww.sis.n webguneko datu-basean. ikura dohainik jaitsi daitezke bere Interneteko jarrizko iturritik.

Todos los documentos que aparecen en este boletín forman parte del fondo documental de la Biblioteca del Siis. Puede solicitarse copia o préstamo de documento, según las normas y tarifas establecidas.

Si está leyendo la versión electrónica del boletín, pulse sobre el número de referencia para acceder a la ficha bibliográfica de la base de datos documental. $\mathrm{Si}$ está leyendo la versión en papel, puede acceder a esa base en $<$ www.sils.net> e introducir dicho número en el campo correspondiente. Los documentos marcados con el símbolo pueden descargarse gratuitamente.
Radiografía de la vida en prisión

\section{GAllego, M. ET AL.}

ANDAR 1 KM. EN LÍNEA RECTA. LA CÁRCEL DEL SIGLO XXI QUE VIVE EL PRESO. SERIE:

Biblioteca Comillas. DeRecho. MAdRID,

Universidad PontiFICIA de COMILLAS, 277 PÁGS., 2010. REF. 196191.

La cárcel es un dispositivo clave en el sistema de seguridad del que nos hemos dotado como sociedad. El funcionamiento de las prisiones tiene un coste notable, pero paradójicamente apenas sabemos cómo viven las 71.649 personas que actualmente están recluidas en ellas en España. El presente estudio busca acercarse a esa realidad a través de la experiencia cotidiana de presos y presas. Con tal fin, un equipo de investigadores de la Universidad Pontificia Comillas ha llevado a cabo la encuesta más amplia jamás realizada a escala estatal entre la población encarcelada. Junto al perfil sociodemográfico de las personas privadas de libertad, se han recabado datos sobre los programas de reinserción y tratamiento, los distintos regímenes penitenciarios, las infraestructuras carcelarias y la atención sanitaria. También se ha indagado en los sentimientos de los internos respecto a las víctimas, así como en sus perspectivas de salida y reincorporación a la sociedad. El libro confirma el nexo entre criminalidad y pobreza, la escasez de medios que faciliten la reeducación y la reinserción, la persistencia de ciertas prácticas contrarias a la dignidad de los presos $\mathrm{y}$, por último, un uso abusivo del encarcelamiento por parte de la Justicia.
Pertsonaren inguruan antolatutako arreta adineko pertsonentzat

MARTÍNEZ, T.

LA ATENCIÓN GERONTOLÓGICA CENTRADA EN LA PERSona / PerTsonarengan

OINARRITUTAKO ARRETA GERONTOLOGIKOA. SERIEA: Documentos de BIENESTAR SOCIALGizARTEA HobetuZ, 76. ZENB. VITORIAGASTEIZ, EUSKO JAURLARITZA-GOBIERNO VASCO, 213 OR., 2011. ERREF.: 191279.

Gaur egun, onartutzat ematen da arreta zerbitzuak erabiltzailearen behar eta desioen inguruan antolatu behar direla, eta ez erakunde edo profesionalen ikuspuntutik, edo haien interesei erantzunez. Hala ere, askotan errazagoa gertatzen da esku hartzeko eredu hori teorian defendatzea, praktikara eramatea baino. Bestalde, desgaitasunak dituzten pertsonen arretaren arloan aski hedatua den eredua izanik, ez du adineko pertsonen zaintzan pareko oihartzunik izan. Zaintza-eredu berritzaile honen oinarri kontzeptuala ezagutaraztea eta berau praktikara eramateko bideak eskaintzea da, hain zuzen, Eusko Jaurlaritzak Matia Fundazioaren lankidetzarekin argitaratu berri duen gida honen helburua. Gidaren kapitulu desberdinetan, pertsonaren inguruan antolatutako arreta garatzeko landu beharreko bost aspektu aztertzen ditu autoreak: autonomia eta independentzia; pribatutasuna, intimitatea eta konfidentzialtasuna; berezkotasuna, esangura, egunerokotasuna; familiak; eta antolaketa eta profesionalak. Kapitulu bakoitzean, jorratutako gaiaren inguruko ideia nagusiak eta jokoan dauden baloreak ezagutarazten dira, ideia horiek praktikara eramateko estrategia metodologikoak, instrumentuak eta jarduera eredugarriak aurkezten dira eta egunerokotasunean sor daitezken zailtasunez ohartarazten da. 
Las políticas sociales bajo el Gobierno británico de coalición

Holden, C. ET AL. (EDS.)

analysis and Debate in Social Policy, 2011. SeRIE: Social Policy REVIEW, № 23. BRISTOL, Policy PRESS, 336 PÁGS. 2011. REF. 195902.

Las elecciones de mayo de 2010 significaron un vuelco en el Gobierno británico, con el relevo del Nuevo Laborismo, en el poder desde 1997, por una coalición formada por conservadores y liberal-demócratas. En un contexto de profunda crisis económica, estos partidos han recortado el gasto público, intensificado la mercantilización del Estado del bienestar y defendido el fortalecimiento de la sociedad civil. El análisis de esta nueva etapa de las políticas sociales en el Reino Unido ocupa la primera parte del presente libro, editado por la Social Policy Association dentro de su serie Review. Las bases ideológicas del Gobierno de David Cameron-calificadas aquí de "paternalismo neoliberal" por el sociólogo Jay Wiggan- son examinadas detenidamente, incluido el concepto de Big Society, que el primer ministro británico utiliza a menudo en sus discursos. Además, se tratan otros temas, como las políticas fiscales y de empleo, el apoyo a las familias monoparentales o la pobreza infantil, que el país quiere erradicar para 2020. La segunda mitad de la obra reúne varios estudios sobre políticas educativas desde una perspectiva internacional.
Modelos de acción socioeducativa

NÚÑEZ, V. (COORD.)

ENCRUCIJADAS DE LA EDUCACIÓN SOCIAL. ORIENTACIONES, MODELOS Y PRÁCTICAS.

SERIE: EdUCACIÓN SOCIAL, № 175

BARCELONA, Editorial UOC, 325 PÁGS. 2010. REF. 196193

En la labor educativa, saber preguntar es (casi) más importante que saber responder. Cabría decir, incluso, que si la persona que educa no se hace las preguntas apropiadas, puede alcanzar fines contrarios a los que inicialmente se planteaba. Este libro es una llamada a que las y los educadores sociales tomen conciencia de los presupuestos teórico-metodológicos desde los que intervienen y de las implicaciones éticas correspondientes. El educador o la educadora social se encuentra, en este sentido, ante dos modelos contrapuestos frente a los que, quiera o no, acaba posicionándose. De un lado, está lo que aquí se denomina modelo neohigienista, en el que la educación opera como un mero instrumento de disciplinamiento y control social. Frente a él, el modelo crítico aboga por mediar entre el sujeto educativo y el patrimonio cultural-concebido como una realidad heterogénea-, favoreciendo la apropiación desde los intereses del propio educando. En el trasfondo de este debate, se sitúa la eterna paradoja educativa en torno a la libertad del sujeto, pues aunque aprender de otro exige cierta renuncia a la autonomía individual, también facilita la plena emancipación.
La atención de menores inmigrantes no acompañados en Europa

KANICS, J. ET AL. (EDS.)

Migrating Alone. UNACCOMPANIEd AND SEPARATEd CHILdREN's Migration to Europe. París, Unesco, 187 PÁGS., 2010. REF. 194008.

La decisión de organizar la conferencia que ha dado lugar a este documento se tomó a mediados de esta década, en un momento en el que el número de menores inmigrantes no acompañados arribados a Europa estaba llegando a su máximo. Ahora, la recesión económica ha contribuido a reducir de manera notable el flujo migratorio de menores, pero el debate sobre el derecho de estos menores a recibir una atención adecuada, adaptada a sus necesidades particulares, continúa, sin embargo, vivo. Este libro, una de las primeras obras colectivas que analiza la inmigración de menores a Europa, constituye una de las aportaciones más importantes a esta discusión. La obra recoge diez de los más de 40 trabajos presentados durante la conferencia. Estos diez capítulos monográficos han sido divididos en dos secciones temáticas. La primera examina los factores que empujan a los menores a buscar un nuevo hogar fuera de su país natal. La segunda parte del volumen aborda los sistemas de acogida en Europa, que, en algunos casos, aseguran los autores, están demasiado centrados en controlar el flujo migratorio para poder ofrecer la protección necesaria a los menores.
Buenas prácticas de atención a personas mayores en el medio rural

Secretaría General del Medio Rural BUENAS PRÁCTICAS EN DESARROLLO RURALY PERSONAS MAYORES. MADRID, MINISTERIO DE Medio Ambiente y Medio RuRAL Y MARINO, 81 PÁGS., 2010. REF. 193766.

Las zonas rurales tienen una tasa de envejecimiento cada vez mayor respecto a la del medio urbano, y en este contexto, trabajar en la mejora de la vida de las personas mayores resulta una forma óptima de contribuir al desarrollo sostenible del medio rural, no sólo en el ámbito social, sino también en el económico y el ambiental. Así, una de las mayores aportaciones de las iniciativas para el desarrollo rural ha sido la creación de servicios de atención a las personas mayores, de los cuales da cuenta el presente documento, que recoge una selección de buenas prácticas llevadas a cabo por entidades sociales y organizaciones de desarrollo rural en todo el territorio español. Entre ellas, cabe destacar los talleres artesanales, los servicios de comida y fisioterapia a domicilio, el programa Activa-T para la promoción del envejecimiento saludable, el programa de balnearios estivales o la Red Social de Personas Mayores y Familias del Medio Rural. Se trata de ejemplos reseñables por su innovación y eficacia en la mejora de la calidad de vida, la promoción del envejecimiento activo y la participación social de las personas mayores del medio rural. 


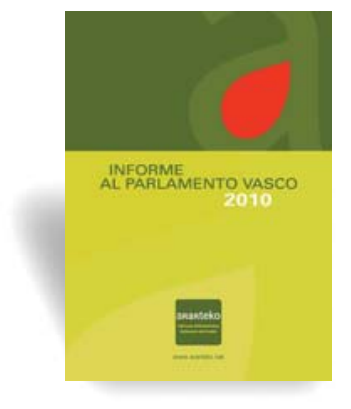

FAMILY

FUTURES

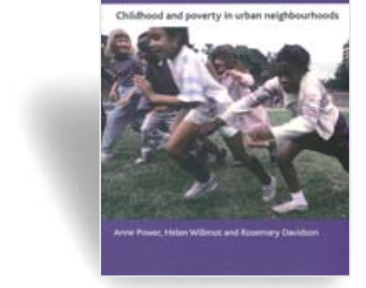

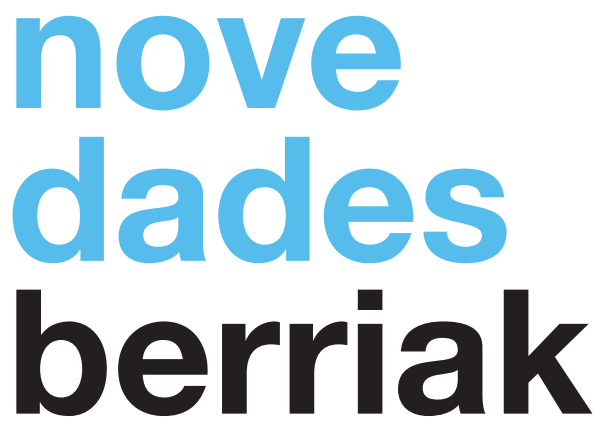

Aumentan las reclamaciones

presentadas al Ararteko en relación al ámbito de lo social

ARARTEKO

INFORME AL PARLAMENTO VASCO 2010 / EUSKO LEGEBILTZARRARENTZAKO TXOSTENA 2010. Vitoria-Gasteiz, Ararteko, 652, 620 PÁGS., 2011. REF. 193704

La institución del Ararteko presentó en junio su informe anual al Parlamento Vasco relativo a las actividades de 2010. El documento refleja que el Ararteko atendió 4.528 consultas (un $3,7 \%$ más que en 2009 ) y 3.158 visitas; de éstas, 734 (un 23\%) se materializaron en quejas y se detectó alguna actuación incorrecta en el $32 \%$ de ellas. Por áreas, las quejas más frecuentes se refirieron a la acción social ( $17 \%)$, que aumentaron respecto de años anteriores. Por administraciones, descienden las dirigidas al Gobierno Vasco (35,7\%), que son superadas por las relativas a la administración local $(42,1 \%)$. En cuanto a territorios, se constata, como en años precedentes, un mayor índice de presentación de quejas en Álava (12,2 por cada mil habitantes), seguida de Bizkaia $(7,4)$ y Gipuzkoa $(6,3)$. En cuanto a la satisfacción de las personas atendidas, el informe señala que el $80,9 \%$ consideran la intervención del Ararteko como muy o bastante positiva. El informe de este año se ha complementado con una extensa separata centrada en la actividad desarrollada por la recientemente creada Oficina de la Infancia y la Adolescencia, que se reseñará en un próximo Boletín.
Ezinbestekoa izango da inbestimenduak mantentzea Erresuma Batuko auzune pobreen etorkizuna bermatzeko

POWER, A. ETA BESTE BATZUK

FAmily Futures. CHILPHOOd ANd Poverty in Urban Neighbourhoods. Seriea: CASE Studies on Poverty, Place and Policy, BRISTOL, POLICY PRESS, 296 OR., 2011. ERREF.: 196399.

Anne Power London School of Economics-eko irakasleak eta beste egile batzuek zortzi urtean egindako azterlanaren arabera, gizarte-inbestimendurik egin ezean, ghetto bilakatzeko arriskuan izango omen dira Erresuma Batuko auzunerik pobreenak. 200 familia elkarrizketatu dituzte epe luzeko azterketa honetan, eta deliberamendu nagusiaren arabera, oso larriak izango omen lirateke baliabideak gutxitu eta familia horiek bizi diren auzuneetan egindako inbestimenduek etena gertatzea. Besteak beste, orain gutxi, istilu larriak bizi izandako Londresko Hackney eta Newham auzoen tankerako familia pobreen egoerak aztertu dituzte txostenean. Auzune horietan hobekuntzarako eginiko esfortzuek mantendu dute nabarmen familia pobreen bizi-maila; eta osasuna, hezkuntza edota ingurumenean egindako inbestimenduak dira familiek gehien balioesten dituzten alorrak.

Elkarrizketatuek hautemandakoaren arabera, garrantzitsu omen dira jasotako zerbitzuak auzoan bizi direnen arteko kohesioa hobetu eta ingurune komunitarioa sendotzeko. Azken batean, familia eta auzune pobretuenek etorkizuna bermatu izateko, inbestimenduak mantendu beharko dira. 

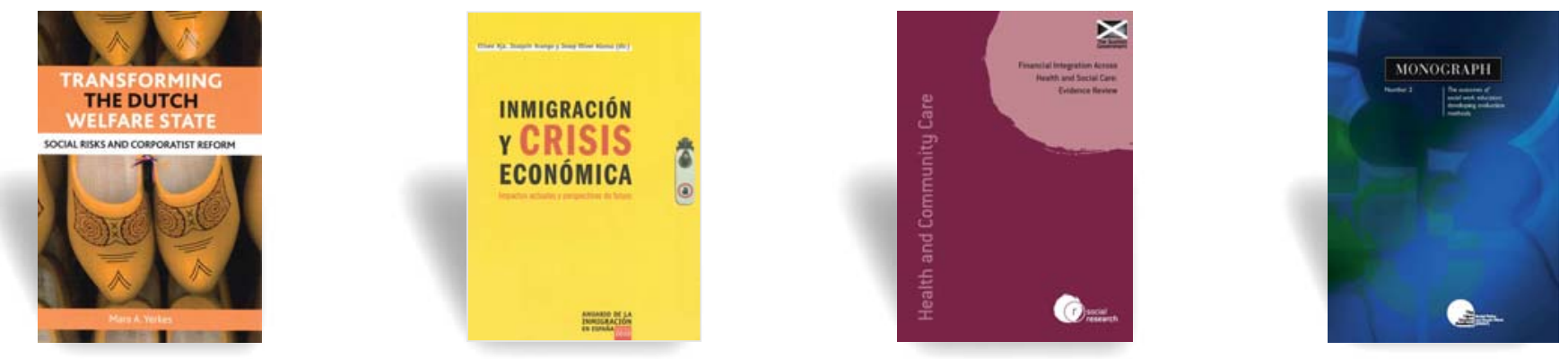

Los agentes sociales ayudan a mantener el Estado del bienestar neerlandés

YERKES, M. A

Transforming the Dutch Welfare State. SOCIAL RISKS ANd CoRporatist REForm. BRISTOL, Policy PRESS, 172 PÁGS., 2011. REF. 196189.

Los Países Bajos, que durante décadas han sido considerados como un referente en el ámbito de las políticas sociales, se enfrentan en la actualidad, al igual que la mayoría de los Estados del bienestar occidentales, a algunos riesgos sociales novedosos y a otros que se han transformado profundamente en los últimos años. Este libro aborda tres de esos riesgos, la atención a la discapacidad, los cuidados de la infancia y la falta de empleabilidad, y analiza cómo el Estado social neerlandés puede afrontarlos. Las opciones en este sentido pasan, como sucede en otros países, por determinar si la responsabilidad de protegerse contra tales riesgos ha de ser colectiva 0 individual. Los autores de este estudio explican que los Países Bajos han logrado pasar de una responsabilidad colectiva a una más individualizada, sin por ello desmantelar la red de protección social. Según los autores, este nuevo 'milagro neerlandés' se ha producido gracias a la estrecha colaboración existente entre el Estado y los agentes sociales. Está aún por ver si este innovador modo de afrontar los retos del Estado de bienestar se convertirá también en un modelo de referencia para otros países.

\section{Espainiako immigrazioaren eraginak eta etorkizunerako gizarte-politikak}

Aja, E. etA beste batzuk (Zuz.)

INMIGRACIÓN Y CRISIS ECONÓMICA: IMPACTOS ACTUALES Y PERSPECTIVAS DE FUTURO. ANUARIO DE LA INMIGRACIÓN EN EsPaña 2010. BARTZELONA, CENTRO DE ESTUDIOS Y DOCUMENTACIÓN

INTERNACIONALES DE BARCELONA, 415 OR., 2011. ERREF.: 195099.

Erroldaren datuen arabera, ehun mila izenemateren hazkuntza ezagutu dute iazko pertsonen migrazioak Espainian. Hazkuntza hori azaltzeko, beste Europako herrialdeetatik etorriak diren pertsonak hartzen dituzte aintzakotzat adituek. 2010 urtea izan da, aurreko urteetako joerak jarraituz, hamarkada batean ezagututako Espainiako immigrazioaren fenomenoaren amaiera urtea. Orekatu egin dira Espainiara sartutako immigrante berriak eta berauen herrietara bueltatutakoen kopuruak. Izan ere, krisialdiak jotako ekonomiaren baitan, behintzat, langabeziaren intentsitatea eta gizarte-mailako ondorioetan galera nabariagoa izan dute immigranteek. Aitzitik, immigranteek lan egindako lanpostuen gutxitzea ez da horrenbesterakoa izan, eta hein batean, behintzat, aurretik aipatutakoaren moduan, immigrante berrien etorrerak azaltzen omen du paradoxa egoera hori. Krisiak eragindako eztabaida horiek eta lan-merkatuaren inguruko ekarpenak jaso dituzte honako argitalpenenaren hasierako ataletan. Horietaz gainera, liburuak jasotako hamabost artikuluetan, hainbat adituk immigrazioaren eta krisiaren egoerak aztertu eta konpondu beharreko Espainiako eta Europar Batasuneko politiken inguruko diskurtsoak azalerazten dituzte.
Integración financiera en el ámbito sociosanitario

\section{WEATHERLY, H. ET AL}

FinanCial INTEgRation aCross Health AND Social Care: Evidence Review.

Edimburgo, Scottish Government Social RESEARCH, 73 PÁGS., 2010. REF. 187442.

Compartir recursos es una de las medidas más habituales para impulsar la eficiencia y la calidad de los servicios sociales y sanitarios, pero no es tan frecuente que esa estrategia se refleje en el plano financiero. Desde abril de este año, el Gobierno escocés viene desarrollando un proyecto piloto con vistas a una integración de servicios y una reordenación de recursos que permitan mejoras en el bienestar de los pacientes. Este informe, que sirve de base a esa iniciativa, trata de identificar y evaluar-mediante la consulta de la literatura internacional- herramientas, técnicas, sistemas y procesos que faciliten la integración financiera y de recursos en el ámbito sociosanitario. Los resultados son algo decepcionantes, pues si bien algunas experiencias mostraron ciertas mejoras en el bienestar de pacientes y cuidadores, o en la autonomía de éstos, la mayoría no tuvieron efectos verificables en la salud de las personas, quizás, en parte, porque prestaron más atención a las variables de proceso, como la ocupación hospitalaria. El trabajo realizado permite, aun y todo, señalar factores críticos e implicaciones metodológicas que merecen tomarse en cuenta en el desarrollo del espacio sociosanitario.
Medición de resultados educativos en trabajo social

BURGESS, H. Y CARPENTER, J. (EDS.) THE OUTCOMES OF SOCIAL WORK Education: Developing Evaluation Methods. SeRIE: MONOGRAPH, № 2 . SOUTHAMPTON, SOCIAL POLICY, AND SOUTHAMP SOCIAL WORK, 130 PÁGS., 2010. REF. 193506.

Las y los trabajadores sociales no sólo deben responder a necesidades cada vez más complejas, sino que, además, se espera que sus intervenciones refuercen la autonomía de las personas usuarias. Estos requerimientos exigen una elevada cualificación, y por eso en el Reino Unido llevan tiempo empeñados en mejorar la docencia que se imparte en las universidades. La calidad educativa se ha evaluado tradicionalmente a través del grado de satisfacción del alumnado, pero este estudio se propone medir los resultados del aprendizaje, manifestados en el cambio de actitudes y percepciones, la adquisición de conocimientos y habilidades, los cambios en la praxis profesional y los beneficios obtenidos por personas destinatarias de las intervenciones sociales. Para ello, investigadores de nueve universidades pusieron en marcha varios grupos de aprendizaje por medio de la acción, en los que participaron docentes, usuarios y cuidadores informales. Dado lo ambicioso del objetivo perseguido, los resultados del informe no pueden ser sino preliminares, pero aun así demuestran, según sus autores, la posibilidad de evaluar progresos en relación a las actitudes racistas, la autoeficacia, las destrezas comunicativas o la compresión de conceptos clave. 


\section{El Gobierno Vasco organiza unas jornadas para debatir sobre el modelo de inclusión activa en la CAPV}

\begin{abstract}
El Departamento de Empleo y Asuntos Sociales del Gobierno Vasco quiere debatir con los agentes sociales las bases conceptuales y filosóficas del modelo de inclusión activa que, con el cambio de la Ley para la Garantía de Ingresos y la Inclusión Social, se pretende aplicar en Euskadi. Para ello, el Departamento organizará una serie de jornadas y seminarios, con la participación de diversos expertos, en las que se analizará y debatirá un documento que recoge las bases conceptuales del nuevo modelo de inclusión activa.
\end{abstract}

A punto de culminar la tramitación de la modificación de la Ley para la Garantía de Ingresos y la Inclusión Social, y de que la gestión de las prestaciones de Garantía de Ingresos sea asumida por el Servicio Vasco de Empleo - Lanbide, el Departamento de Empleo y Asuntos Sociales del Gobierno Vasco quiere debatir con todos los agentes sociales que intervienen en este ámbito acerca de las bases conceptuales del nuevo modelo de inclusión activa. El debate se basará fundamentalmente en la discusión de un documento elaborado, a instancias del Departamento, por el SIIS Centro de Documentación y Estudios en el que se plantean las bases teóricas en las que deberían sustentarse en el contexto de la CAPV las políticas de activación y las características que debería tener en ese contexto un modelo inclusivo de activación.

El objetivo del informe es el de proponer una serie de líneas de reflexión, de carácter teórico, sobre la aplicación del concepto de activación a la gestión de las políticas de garantía de ingresos y de empleo, que sirva de marco conceptual y filosófico al modelo de intervención de Lanbide. El informe pretende contextualizar el proceso de cambio que se está desarrollando en la CAPV en el marco teórico desarrollado en torno al paradigma de la activación y, a partir de esa reflexión, proponer un modelo de intervención, en el ámbito de la activación de las personas perceptoras de prestaciones de garantía de ingresos, respetuoso con los derechos de toda la ciudadanía. Para ello, el informe ofrece una descripción global de las políticas de activación introducidas en los países de nuestro entorno desde, al menos, la década de 1980 , y consideradas por numerosos autores como un cambio de paradigma en relación al modelo tradicional de Estado del Bienestar. Una vez presentadas las principales características que se le atribuyen al paradigma de la activación, la forma en la que sido introducido en los países de nuestro entorno y lo que representa de ruptura, o de continuidad, con los enfoques tradicionalmente aplicados en la CAPV, el informe repasa con cierto detalle las principales críticas que se le han hecho, al objeto de evaluar en qué medida se trata de un modelo aplicable a nuestro entorno $\mathrm{y} / \mathrm{o}$ en qué condiciones debería aplicarse para resultar adecuado desde un punto de vista filosófico o conceptual.

A partir de esas reflexiones, el trabajo realizado por el SIIS plantea las bases teóricas en las que deberían sustentarse en el contexto de la CAPV las políticas de activación, y propone las características que debería tener un modelo inclusivo de activación en la CAPV.

Está previsto que la primera sesión de las jornadas se celebre a finales del mes de octubre en Vitoria-Gasteiz. A ellas se invitará a una representación de las principales entidades públicas y privadas de la CAPV que trabajan en este ámbito. En la jornada intervendrán, además de los redactores del documento, expertos como Imanol Zubero, profesor de la UPV, Begoña Pérez Eránsus, de la Universidad Pública de Navarra, y Luis Sanzo, sociólogo y responsable del Órgano Estadístico Específico del Departamento. Posteriormente, en el mes de noviembre, se celebrarán una serie de jornadas de presentación, una en cada Territorio. El resultado de todo el proceso -escuchadas las aportaciones de todos los agentes- será la elaboración por parte del Gobierno de un documento o decálogo que oriente durante los próximos años las políticas de empleo y de garantía de ingresos en la CAPV. 


\section{Bases conceptuales para la inclusión activa}

El documento de trabajo elaborado en torno a la activación y el derecho a la inclusión en el marco de las políticas de empleo y de garantía de ingresos en la CAPV establece un modelo basado en los siguientes elementos: - Centralidad del empleo como
mecanismo de inclusión. Aun reconociendo la erosión que la extensión del empleo precario ha provocado en la capacidad inclusiva del empleo, y el hecho de que no siempre la inclusión social pasa necesariamente por la inclusión laboral, el modelo que se propugna parte de la base de que el empleo constituye en nuestros días un mecanismo esencial de inclusión social, de realización personal y de protección contra la pobreza.

- Doble derecho. El modelo apuesta por la materialización efectiva del principio de doble derecho, en el sentido de que debe reconocerse a las personas en situación o riesgo de exclusión social tanto el derecho a recibir apoyos de calidad para la inserción social y laboral y para la mejora de la empleabilidad, como el derecho a la percepción de una renta mínima adecuada en caso de insuficiencia de recursos propios. El modelo parte de la necesidad de reconocer de forma efectiva ambos derechos y de poner los medios necesarios para que ambos, y no sólo uno de ellos, puedan ser ejercidos por la ciudadanía.

- Condicionalidad. En el modelo que se propugna, el derecho a la garantía de ingresos se basa en una interpretación en clave ética de la autonomía individual, en virtud de la cual todas las personas deben contribuir razonablemente, en la medida de sus posibilidades, a la construcción del bien común en el marco de un sistema que establece tanto derechos como deberes a toda la ciudadanía. Al mismo tiempo, se considera que las personas perceptoras de prestaciones económicas asistenciales deben realizar los esfuerzos razonablemente posibles para salir de la situación de necesidad que justifica la percepción de esas prestaciones. La legitimidad del principio de condicionalidad aplicado a las obligaciones laborales parte de una noción de la justicia distributiva basado en la idea de la reciprocidad: todo aquel que voluntariamente se beneficie del producto social asume el correspondiente deber de realizar a cambio una contribución productiva, razonable y proporcional, a la comunidad.

- Reciprocidad justa. La obligación de realizar alguna aportación al bien común que subyace al principio de reciprocidad no puede sin embargo establecerse al margen del contexto socioeconómico en el que se aplica, del marco concreto de distribución de los bienes y las oportunidades en el que se materializa. La legitimidad del mecanis mo contractual que subyace a la activación depende por tanto de la medida en la que colectividad respeta unos criterios básicos de igualdad, redistribución y justicia social. Desde ese punto de vista, el concepto de reciprocidad justa subraya la necesidad de que, para poder aplicar legítimamente el principio de condicionalidad antes señalado, desde las administraciones públicas y desde el conjunto de la sociedad, se respeten unos mínimos básicos en términos de igualdad de oportunidades, redistribución y calidad en el empleo.

- Doble compromiso. Todo ello exige un doble compromiso: el que asumen las personas en situación de desempleo o exclusión para la mejora de su situación y para la realización, en la medida de sus posibilidades, de una aportación productiva al bien común, y el que asume la sociedad al proveer a las personas en situación de necesidad de una renta de garantía de ingresos adecuada y de unos apoyos para la inclusión, y al garantizar un contexto socioeconómico razonablemente justo.

- Empleabilidad amplia. El modelo parte de una interpretación amplia del concepto de empleabilidad, basado tanto en la adecuación de las habilidades y características individuales a las necesidades del mercado de trabajo, como en la necesidad de incidir factores estructurales, como la demanda de empleo o las condiciones del mercado de trabajo.

- Rentabilización del empleo. Igualmente, el modelo se basa en la necesidad de desarrollar las llamadas políticas de rentabilización del empleo o making work pay con el objeto de incentivar el acceso al empleo y, sobre todo, de incrementar los ingresos de los trabajadores de bajos salarios, reforzando la capacidad insertadora de este tipo de empleos. Este tipo de medidas requieren un cambio en la concepción y en el diseño de las prestaciones económicas de garantía de ingresos, que ha de pasar de una lógica de sustitución de rentas a otra de complementación.

- Inclusión social. La multicausalidad de la exclusión sólo puede ser abordada desde una concepción multidimensional de la inclusión, no exclusivamente centrada en la inserción laboral (por más que, como antes se ha dicho, ésta se considere el mecanismo básico de inclusión social y protección frente a la pobreza). Ello abre la puerta a la conveniencia de abordar en los procesos de inclusión cuestiones distintas a la de la empleabilidad y/o de trabajar a partir de una concepción más amplia del trabajo, que no se limite al empleo remunerado y reconozca otras aportaciones posibles, como el trabajo voluntario o los cuidados familiares. La aplicación del concepto de inclusión social, en la línea del modelo social de la discapacidad, implica también la idea de que, más allá de adaptar las personas a las necesidades del mercado de trabajo, es necesario adaptar el mercado de trabajo a las necesidades de las personas.

- Individualización. El modelo de inclusión activa que se propugna se basa igualmente en la individualización de las intervenciones, tanto en lo que se refiere a la adecuación de los servicios prestados a las necesidades específicas de las personas y a la fase del proceso de inserción en la que se encuentran, como a la participación de las personas afectadas en la definición de los objetivos y los contenidos de las intervenciones.

- Territorialización. La descentralización de las intervenciones y la creación de redes de partenariado sobre una base local o comarcal constituye otro de los elementos básicos del modelo.

- Servicios de apoyo. El modelo propuesto requiere de una apuesta decidida por los servicios de apoyo, tanto en las diversas fases de la inserción laboral (incluyendo el periodo posterior a la colocación) como en lo que se refiere a la prestación de servicios que faciliten la inserción laboral (conciliación familiar, ayudas al transporte, etc.). El modelo se basa igualmente en el reconocimiento del determinante papel que los Servicios Sociales han de jugar en cuanto al trabajo social para la incorporación de las personas perceptoras de prestaciones de garantía de ingresos. Este trabajo social puede definirse como un proceso de acompañamiento del desarrollo personal en el contexto de la comunidad. 


\section{entrevista \\ elkarrizketa}

\section{'Proponemos un modelo de inclusión activa que contempla la mejora de la empleabilidad como un derecho social básico'}

\section{Javier Ruiz}

Javier Ruiz es Viceconsejero de Planificación y Empleo, y uno de los responsables de pilotar el proceso de traspaso de las competencias de gestión de la RGI desde los Ayuntamientos y las Diputaciones a Lanbide. En esta entrevista, Ruiz explica el proceso de debate que se quiere seguir y las bases del modelo de activación inclusiva que se quiere aplicar en Euskadi.
El Departamento de Empleo y Asuntos Sociales del Gobierno Vasco organizará en breve unas jornadas para presentar y discutir un documento, elaborado por el SIIS, en torno al modelo de inclusión activa en la CAPV. ¿Cuál es la finalidad de ese documento?

Su finalidad es la de contribuir a la reflexión y el debate sobre el modelo de inclusión activa que debemos desarrollar en la CAPV. Queríamos disponer de un documento, de una especie de libro blanco, que nos orientara en la reflexión sobre el significado del concepto de activación y sobre la forma más adecuada de aplicarlo. El documento elaborado repasa el significado del paradigma de la activación, analiza en qué medida ese paradigma ha estado históricamente presente en el desarrollo del sistema vasco de garantía de ingresos y, sobre todo, propone un modelo concreto, a partir de unas bases conceptuales y filosóficas con las que el Departamento está, en líneas generales, de acuerdo. Obviamente, no necesariamente suscribimos el documento en su totalidad, pero creemos que aporta una propuesta razonable y razonada para el debate, y que plantea un modelo respetuoso con los derechos de toda la ciudadanía. Creo además que el documento confirma y argumenta, desde el punto de vista teórico, muchas de las medidas y de los enfoques que hemos ido aplicando desde el Departamento de Empleo y de Asuntos Sociales en materia de garantía de ingresos. Ahora queremos someter ese documento a una discu- sión más amplia, escuchar la opinión de los expertos y de los agentes que intervienen en este campo sobre los aspectos que plantea y, a partir de esa reflexión, elaborar un documento programático propio que nos ayude a orientar nuestra labor en este ámbito.

El documento parte de la base de que no hay un solo modelo de activación y de que, dependiendo de cómo se aplique, el paradigma de la activación puede resultar un avance, y no un retroceso, en términos de derechos sociales. ¿Cómo conseguir ese objetivo? El documento señala efectivamente que las políticas sociales de los países de nuestro entorno se han visto radicalmente modificadas por el paradigma de la activación, que en líneas generales establece una mayor vinculación entre las políticas de inserción social y las de inserción laboral, aunque existen fórmulas muy distintas, incluso contrapuestas, de llevar a la práctica ese paradigma; algunas de ellas han supuesto un recorte de derechos y otras, por el contrario, un avance en los derechos de las personas. Lo que queremos es determinar cuáles son los elementos conceptuales que permitan el desarrollo de un modelo de activación inclusivo, respetuoso con los derechos de toda la ciudadanía.

¿Supone el modelo propuesto un cambio con el que tradicionalmente se ha aplicado en Euskadi?

No; es evidente que, desde sus inicios, el sistema vasco de rentas mínimas ha tenido muy presente la necesidad de combinar protección social y activación laboral, y que desde un primer momento se apostó por la centralidad del empleo como mecanismo básico de inclusión social y de protección contra la pobreza. Como señala el informe, no puede sostenerse que la introducción de medidas tendentes a la activación laboral de las personas perceptoras de prestaciones de garantía de ingresos suponga una ruptura con el modelo preexistente en nuestro país, ni que, en sí mismas, las políticas de activación erosionen o vayan en detrimento de los derechos de ciudadanía hasta ahora reconocidos en Euskadi. De hecho, los cambios que estamos introduciendo avanzan en el sentido 
de reforzar el concepto de doble derecho. Hasta ahora el derecho a la prestación económica ha estado razonablemente garantizado, pero no hemos avanzado lo suficiente en lo que se refiere a garantizar el derecho a recibir los apoyos necesarios para la inserción social y laboral. El enfoque que defendemos se basa en la idea de que la mejora de la empleabilidad y los apoyos para la inclusión constituyen un derecho social, un derecho de las personas en situación de desempleo o de exclusión tan importante como el derecho a la garantía de ingresos, si no más. Partimos, eso sí, de un concepto de empleabilidad que tiene en cuenta tanto los condicionantes y circunstancias individuales como los condicionantes estructurales que se refieren a la demanda de empleo y a las condiciones del mercado de trabajo.

¿En qué medida el sistema de rentas mínimas que se plantea tiene un carácter condicional? El sistema de rentas mínimas debe contar con el mayor consenso y apoyo ciudadano posible, para ser legítimo, y creo que la mayor parte de la ciudadanía es partidaria de aplicar determinadas condiciones a la RGI. Y, al margen de esta cuestión, desde un punto de vista más conceptual, creemos que el establecimiento de unos criterios mínimos de condicionalidad está éticamente justificado en la medida en que creemos que el Estado del Bienestar implica, para la ciudadanía, tanto derechos como responsabilidades. También creemos que las personas que reciben prestaciones económicas financiadas por el conjunto de la ciudadanía deben hacer un esfuerzo para salir de la situación en la que se encuentran. Eso sí, nos parece muy interesante la idea de la reciprocidad justa que plantea el informe, en el sentido en que la exigencia de una cierta reciprocidad a los perceptores de prestaciones económicas sólo puede ser legítima si se cumplen unas condiciones mínimas en términos de igualdad de oportunidades o justicia social. Entre ellas, nos parece básica la intervención pública para la creación de empleo y la regulación del mercado de trabajo, de forma que el empleo no pierda su capacidad inclusiva. También nos parece adecuado el concepto de doble compromiso: el que asumen las personas en situación de desempleo o exclusión para la mejora de su situación y para la realización, en la medida de sus posibilidades, de una aportación productiva al bien común, y el que asume la sociedad al proveer a las personas en situación de necesidad de una renta de garantía de ingresos adecuada y de unos apoyos para la inclusión, y al garantizar un contexto socioeconómico razonablemente justo.

¿En qué medida el empleo precario ha destruido la capacidad insertadora del empleo? Es cierto que la precarización del mercado de trabajo nos debe hacer reflexionar sobre la centralidad del empleo como eje principal de inclusión, pero no se trata de renunciar a que estas personas puedan trabajar, sino de incidir en las barreras sociales e individuales que impiden el acceso de estas personas al empleo. Es obvio que no todos los empleos tienen el mismo potencial para generar bienestar, felicidad, inclusión o calidad de vida. Pero también es verdad que incluso un empleo precario, en la medida en que favorezca la transición hacia situaciones con mayor capacidad inclusiva, puede tener gran utilidad en un proceso de inserción. En cualquier caso, lo que no puede sostenerse es que la mera percepción de una prestación económica resulte, en sí misma y por sí sola, más inclusiva que la integración en un puesto de trabajo: sólo en el caso de que esa prestación económica se inserte en un proceso de avance hacia la inclusión podrá hablarse de una diferencia positiva de la prestación frente a determinados empleos.

\section{¿Cuáles son, desde un punto de vista más} práctico, las herramientas de las que dispone el sistema?

Nuestro reto está ahora en poner a punto la caja de herramientas de las que debe disponer el sistema, para poder cumplir con nuestra parte del compromiso. Queremos trabajar en ese sentido desde un enfoque basado en lo local, en el territorio, en coordinación con todos los agentes. Y las herramientas que tenemos son muchas (orientadores laborales, empresas de inserción, convenios de inclusión, cláusulas sociales, empleo pro- tegido, medidas de estímulos al empleo...), aunque en algunos casos será necesario mejorarlas y afinarlas. Todo ello, en cualquier caso, de una perspectiva individualizada, adaptada a las necesidades y a las expectativas de las personas con las que trabajamos, pero que no deje de tener en cuenta los factores estructurales que inciden sobre las situaciones de desempleo y de exclusión.

Y, en este marco, ¿cuál ha de ser el papel de los Servicios Sociales, una vez que las competencias de gestión de la RGI pasen a Lanbide? Desde luego, el modelo que propugnamos no parte de la base de que sean los Servicios Sociales los responsables de abordar, de forma exclusiva, el conjunto de las problemáticas de las personas desempleadas o en situación de exclusión social, en nombre de una presunta responsabilidad global sobre este tipo de situaciones. Al contrario, la lógica de la asunción por parte de Lanbide de las competencias en materia de gestión de la RGI radica precisamente en la transversalidad de la política de inclusión social y en el hecho de que de que cada una de las prestaciones 0 ayudas económicas debe gestionarse desde el sistema o ámbito más afín a su naturaleza. Es un error, en ese sentido, pensar que la gestión de la política de garantía de ingresos desde los Servicios Sociales es más coherente con la concepción multicausal de la exclusión social que su gestión desde los servicios de empleo: si hablamos del abordaje de la exclusión social, tan parciales y sectoriales son los servicios sociales como los de empleo, como los de salud, o como cualquier otro. El modelo que se propugna en este documento parte de la base de que no hay un sistema o ámbito con visión global y transversal, y de que cada uno de los sistemas debe realizar su propia aportación a los procesos individuales de inserción. En ese marco, consideramos que los servicios sociales deben centrarse en la prestación de apoyos personalizados para la mejora de la autonomía funcional y la integración relacional, y en la realización de un trabajo social para el acompañamiento de los procesos para la incorporación social. 


\section{Zer da bizimodu independentea? Eskubidea versus errealitatea, Gipuzkoako esperientzia}

\section{Xabier Urmeneta}

xurmeneta@gipuzkoa.net

GIPUZKoAKo Foru ALdUNDIAN TEKNIKARIA

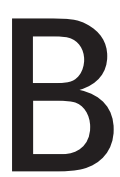

izimodu Independenterako mugimendua AEBetan sortu zen duela 40 bat urte, desgaitasuna zuten pertsona batzuek bultzatuta. Haren printzipioak honako hauek dira: burujabetza; giza eskubideak, bereziki eskubide zibilak; elkarri laguntzea; boterea izateko aukera (jabekuntza); eta nork bere bizitzaren ardura hartzea. Diru-laguntzak

('ordainketa zuzenak') eta laguntzaile pertsonalak dira eskatutako baliabideak. Bizimodu Independentearen oinarri legala, Nazio Batuen Erakundeak ezarri zuen, Desgaitasuna duten Pertsonen Eskubideei buruzko Hitzarmenaren eta bere Protokoloaren bidez. Hitzarmen horrek medikuntzaren birgaitzeeredua baztertu eta eredu soziala indartu du; beraz, gizarteratzeko esfortzua ez du pertsonak egin behar, gizarteak baizik. Halaber, oinarrizko giza eskubide guztiak ez ezik, aitortzen ditu osasuna, birgaitzea eta lan inklusiboa lortzeko eskubideak ere.

Gure gaiari begira, bizimodu independenterako eskubidea aitortzen du 19. artikuluak. Artikulu horretan, hitzarmenak errekonozitzen du laguntza pertsonalerako eskubidea eta nork bere bizimodua erabakitzekoa. Horrela, Estatu parte-hartzaileek ziurtatuko dute "desgaitasuna duten pertsonek -gainontzekoen antzeko baldintzetan- non eta norekin bizi nahi duten hautatzeko aukera izan dezatela eta ez daitezela bizimodu sistema espezifiko baten arabera bizitzera behartuta egon". Eta jarraian esaten du “eskubidea dute, orobat, beharrezkoa den laguntza pertsonala izateko, beren bizimodua eta komunitatean sartzea errazteko eta bertatik isolatu edo aldentzea ekiditeko".

Gaur egun, aipatutako hitzarmenaz gain, Estatuko erreferentzia nagusia da 39/2006 Legea, autonomia pertsonala sustatzeari eta mendetasun-egoeran dauden pertsonak zaintzeari buruzkoa. Estreinako aldiz, mendekotasuna da garrantzizkoa, ez desgaitasuna. Eta erabateko aldaketa ekarri du lege horrek: mendekotasun egoeran daudenek eskubide subjektiboa dute gauza batzuk eskatzeko. Autonomia Erkidegoei begiratuz gero, oraingo honetan hiru programa soilik daude abian: Gipuzkoan, Madrilen eta Bartzelonan, eta elkar bereizten dituzten ezaugarri nagusiak aldameneko taulan azaldu ditut. Horietaz gain, badaude beste esperientzia batzuk (Andaluzian, Galizian, Valentzian eta Katalunian); baina bi eredu erabiltzen dituzte, eta, nire ustez, ez dira nahikoak bizimodu independentea erabat bermatzeko. Alde batetik, etxez etxeko zerbitzu indartuak ordu gehiago eskaintzen baditu ere, mugatuta daude ordu horiek, eta ezin da aukeratu laguntzaile pertsonalik ezta ordutegirik ere. Bestetik, laguntza pertsonalerako prestazio ekonomiko zabalagoak diru gehiago banatzen du, baina beharrak ez ditu neurtzen, eta 'denontzako kafea' delakoaren eredua da.

Bizimodu Independenteak esparru juridiko propioa behar du. Gure inguruneari dagokionean, Autonomia Pertsonala sustatzeko Legeak betetzen du esparru hori. Baina, zoritxarrez, 39/2006 Legeak ez du errekonozitzen bizimodu independentea, laguntza pertsonala bakarrik aitortzen du. Horrela, nire ustez, galdutako aukera bat izan da lege hori. Izan ere, hainbat alderdik modu desberdinetan mugatzen dute legea, eta hauek nabarmenduko nituzke horien artean: dirukopuru finkoa (malgutasunik gabe); dirulaguntza eskubidea mendekotasun egoerari lotuta dago, eta bakar-bakarrik hirugarren gradukoei emateko dira; eta erkidego batzuek -nire ustez, oso interpretazio murriztailea eginez- ikasteko edo lan egiteko soilik ematen dute. Esanak esan, eta haratago joanda, hor dago diru-kopuru bat 
laguntza pertsonala eta bizimodu independentea martxan jartzeko, eta, nahitaez, kontuan hartu behar da bizimodu independentearen programa abian jartzerakoan.

Gipuzkoako Bizimodu Independenterako Programak oinarritzat dauzka ordainketa zuzena, pertsonaren kudeaketa zuzena eta Administrazioaren eta pertsonaren arteko harreman zuzena. Horrela, pertsona bakoitzak bere Bizimodu Independenterako plana proposatzen du, eta elkarrizketa prozesu batean erabakitzen da zer diru-laguntza jasoko duen. Diru horrekin, pertsona bakoitzak bere laguntzaile pertsonalak aukeratzen ditu, hau da, kontratatu, ordaindu eta Gizarte Segurantzan alta eman behar die. Dena den, beste administrazioetatik helburu berberaz emandakoaren diru-kopuru osagarria izaten da. Beraz, kontuan hartzen dugu batetik Gizarte Segurantzak emandako dirua -baliaezintasun handia izateagatiko osagarria, hirugarren baten laguntzarako osagarriak- eta bestetik 39/2006 Legeak sortutako prestazio ekonomikoak -bereziki, Laguntza Pertsonalerako Prestazioa-. Oinarrizko arrazonamendua hauxe da: jasotako diru-laguntzekin nahiko ez baduzu, Bizimodu Independentearen Programaren bidez, Gipuzkoak osatuko dizu dirulaguntza zure bizimodu independenterako adostutako planaren arabera. Eta behin dirulaguntza adostuta, urteko diru emakida egiten da. Dena den hamabi epetan ordaintzen $\mathrm{da}$-hilero-, eta zuriketa egin behar da hurrengo urteko urtarrilean.

Programa 2004an hasi zen -lehenengo esperientzia Estatuan-, eta lau lagunek hartu zuten parte. Gaur egun, 39 lagun daude sartuta, eta mendekotasun handia dute gehienek. Horrela, hirugarren graduko 20 pertsona; bigarren graduko hamalau, eta lehen graduko lau dira -horrez gain, desgaitasuna izan arren, menpekotasunik gabeko pertsona bat dago-. Programa ez da garestia, behintzat, egoitzen kostua hartuz gero: 400.000 euro aurreikusi dira aurtengoan. Dena den, horrek ez du esan nahi diru hori bakarrik erabiltzen denik; izan ere, gure programan kontuan hartzen dugu beste administrazioek emandako hauek ere: bereziki, Gizarte Segurantzaren prestazioak eta, besteen artean, laguntza pertsonalerako presta-

\begin{tabular}{ll}
\hline Estatuan abian diren bizimodu independentea lortzeko proposamenak \\
\hline Gipuzkoa & $\begin{array}{l}\text { Ordainketa zuzena egiten da, eta norberak kudeatzen ditu, bai diru-kontuak, bai lagun- } \\
\text { tzaile pertsonalak. } \\
\text { - Administrazioak berak kudeatzen du programa. }\end{array}$ \\
\hline Madril & - Laguntzaile pertsonala norberak aukeratzen du, baina Oficina de Vida Independiente-k \\
& betetzen ditu kudeaketa gaiak. \\
- Erakunde batek kudeatzen du programa hitzarmen bidez. & \\
\hline Bartzelona & - Laguntza pertsonalaren orduak banakoaren beharren arabera egokituak, mugarik gabe. \\
& Derrigorrean, enpresa baten bidez jaso behar dute zerbitzua (Bartzelonako Oficina de \\
& Vida Independiente edo beste bat).
\end{tabular}

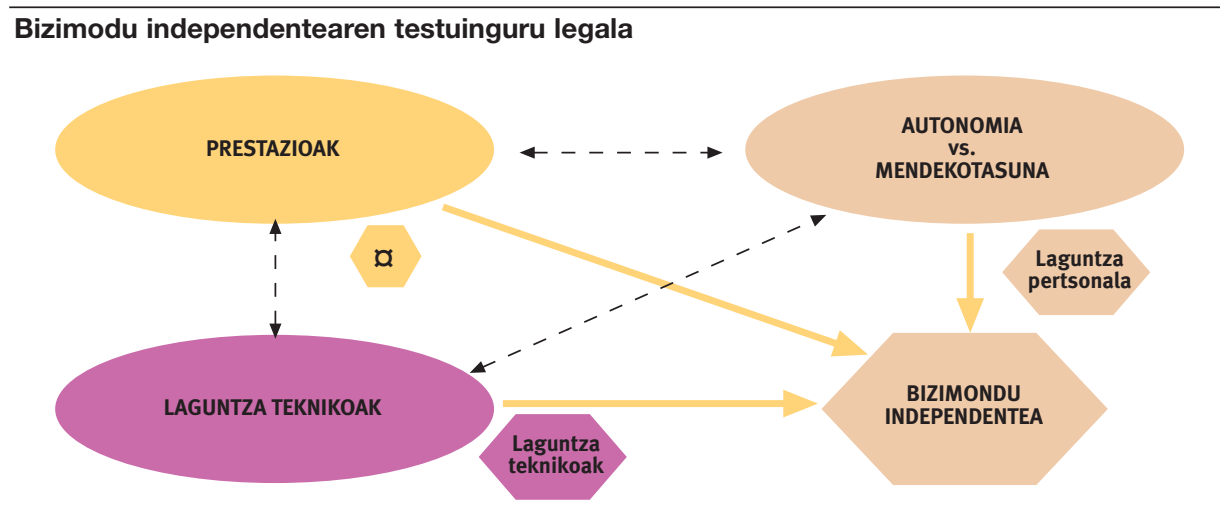

zioa. Orain arte, lau baja izan dira: bi pertsona hil dira, eta beste bik erabaki dute egoitza batera sartzea.

Programan sartzeko, Gipuzkoan erroldatuta egon beharraz gain, beste betebehar batzuk daude. Esaterako, norberaren segurantza eta babesa ziurtatzeko gaitasuna eta laguntza sare bat izatea. Gainera, nork bere familia osatua izatea, hots, ezin da sartu programan gurasoen etxean bizi izanez gero; horrez gain, betebeharrekoak dira bizilekua izatea -bai alokairuan bai jabetzan- eta zentzuzko bizimodu independenterako plana aurkeztea. Normalean, bai kontratua bai alta Gizarte Segurantzan eskatzen dira -oso ordu gutxi ez badira-, eta norberak kudeatzen ditu laguntzaile pertsonalak -altak, bajak, ordainketak, oporrak-. Gaur egun, senitartekoak ezin dira laguntzaile pertsonalak izan. Hainbeste gauza kudeatzea ez da erraza, eta pertsona guztiek ez daukate beharreko ezagutzarik edo kemenik horiek guztiak egiteko. Gauzak horrela, kooperatiba sortu berria dute erabiltzaileek.

Bizimodu independentea ez da ezeretik sortzen; programa gauzatzeko, gauza batzuk behar ditugu, eta, nire ustez, oinarrizko programen artean laguntza teknikoak indartu behar dira:. Hau da, pertsonak laguntza teknikorik izan ezean, laguntza pertsonalaren premia gehiago izango du gauzak egiteko. Era berean, zenbat eta mendekotasun handiagoa izan, orduan eta gehiago beharko du laguntza pertsonala; eta horren ondorioz, laguntza pertsonalak lortzeko diru gehiago. Izan ere, sistema batean gaude, eta hiru elementu horiek lotuta daude elkarri. Gainera, aldagai lotuak direnez, bat jaisten bada, besteek igo beharra dute bizimodu independentea mantentzeko. Baina ez dugu ahaztu behar gaiaren gako nagusia: laguntza pertsonala, hau da, kalitatezko laguntza pertsonala. Hori gabe ezin da bizimodu independenterik egin. 


\section{El impacto de la crisis económica sobre la cohesión social}

Un amplio estudio realizado por la Fundación FOESSA pone de manifiesto el importante crecimiento de las tasas de pobreza y precariedad como consecuencia de la crisis económica, que ha afectado de forma especialmente dura a los sectores que previamente ya eran más vulnerables. En torno al $25 \%$ de la población ha visto cómo empeoraba su situación en términos de integración social, y los sistemas de protección social, pese al incremento en el número de hogares beneficiarios, no han podido compensar los efectos del desempleo. Ante este panorama, los autores del informe reclaman una amplia reforma de los sistemas de ingresos mínimos, con la refundación, a medio plazo, de las rentas mínimas autonómicas.

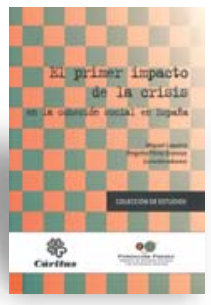

LaparRa, M., y PÉrez ERANSUs, B. (COORds.) EL PRIMER IMPACTO DE LA CRISIS EN LA COHESIÓN SOCIAL EN ESPAÑa. SERIE: Estudios, № 32. MADRID, FUNDACIÓN FOESSA, 519 PÁGS., 2010. REF. 196412.

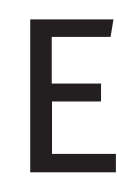
n 2008, apenas iniciada la actual crisis económica, la Fundación FOESSA publicaba su VI Informe sobre la situación social en España. El estudio se basaba, fundamentalmente, en la explotación de una encuesta demográfica realizada en 2007 a partir de una serie de indicadores que recogían el carácter multidimensional de la exclusión social, y con el que fue posible agrupar a la población española -de acuerdo a su situación personal y familiar- en cuatro grandes grupos: la integración plena, la precariedad integrada (o integración precaria), la exclusión compensada y la exclusión severa. La aplicación de esa batería de indicadores a una encuesta representativa de la población española permitió, por primera vez, disponer de una herramienta a escala estatal capaz de analizar la situación en términos de exclusión social, y no únicamente de pobreza o privación material, y conocer además el efecto de las políticas sociales públicas en esas situaciones.

Dos años después, en el segundo semestre de 2009, la Fundación FOESSA ha vuelto a realizar un examen parecido, utilizando un cuestionario similar y la misma batería de indicadores, para calcular los efectos de la actual crisis económica y financiera sobre la cohesión social en España. Si bien hace algunos meses ya se presentó un avance de este trabajo, la fundación acaba de hacer público un amplio informe en el que, a través de catorce capítulos monográficos, se analiza no sólo el impacto de la crisis sobre los niveles de integración social y las tasas de pobreza y desigualdad, sino también el papel que en la contención de las situaciones de exclusión han jugado los sistemas de ingresos mínimos; el papel que, en este ámbito, deben jugar los servicios sociales; las repercusiones específicas de la crisis en colectivos tales como las personas inmigrantes o con discapacidad, y en los diferentes ámbitos territoriales; la vivencia subjetiva de la crisis, su efecto en las relaciones sociales; o su influencia en lo que se refiere a la participación política de las personas afectadas por procesos de exclusión. Se trata de un informe de lectura obligada para cualquier persona que trabaje en el ámbito de las políticas sociales, tanto por el interés de sus conclusiones generales como por la riqueza de los análisis sectoriales realizados. Sus conclusiones son claras: la crisis ha multiplicado las situaciones de pobreza y precariedad, sin que las prestaciones del sistema de protección social hayan sido capaces de compensar las consecuencias del incremento del desempleo.

Desde el punto de vista metodológico, cabe destacar el carácter parcialmente longitudinal de la encuesta realizada en 2009: algo más de la mitad de la muestra original de 2007 fue entrevistada de nuevo en 2009, con lo que se puede conocer tanto el cambio en la situación concreta de esas familias en estos dos años de crisis, como las diferencias relativas al conjunto de la muestra de cada año.

\section{Un millón más de pobres}

El informe se inicia con un trabajo de Olga Cantó y Luis Ayala en el que se pasa revista, a través de fuentes estadísticas secundarias, a los efectos de la crisis en términos de pobreza y privación material. Los datos de la Encuesta de Condiciones de Vida son claros en ese sentido: tras años de estabilidad, entre 2006 y 2010 la tasa de pobreza de las personas adultas pasó del $16,4 \%$ al $19,1 \%$, lo que supone un incremento del $16 \%$ y, en términos absolutos, un millón más de personas 
bajo el umbral de pobreza relativa, sólo en ese tramo de edad. Los datos que Ayala y Cantó extraen de la Encuesta de Presupuestos Familiares ponen también de manifiesto que son los hogares que anteriormente contaban con menos ingresos los que, en mayor medida, han visto cómo se deterioraba su situación, mientras que en el caso de los más favorecidos, la situación ha mejorado, y entre los grupos intermedios, se ha mantenido. En efecto, los datos de las diversas encuestas revelan un efecto mucho más negativo de la crisis sobre los ingresos de los hogares con menores recursos que sobre los más ricos. Todo ello ha provocado un aumento de la incidencia y la intensidad de la pobreza, y un incremento de las tasas de desigualdad, sobre todo debido al fuerte retroceso en la situación de las personas que antes de la crisis ya eran menos favorecidas. Este aumento de la desigualdad, concluyen los autores, podría tener consecuencias duraderas, ya que -recuerdan citando la experiencia de crisis anteriores- los niveles de equidad anteriores a la desaceleración y la destrucción de empleo pueden no recuperarse a largo plazo.

Los datos más novedosos, en cualquier caso, son los que ofrecen Ángel García y Miguel Laparra al explotar la segunda ola de la encuesta FOESSA. El primer resultado de su trabajo es la constatación del aumento de la precariedad y la exclusión social como consecuencia de estos dos años de crisis: si se tiene en cuenta el conjunto de la muestra, las situaciones de integración plena han caído más de diez puntos, pasando del $47 \%$ al $37 \%$ de la población; las situaciones de exclusión severa o moderada han crecido ligeramente; y lo que verdaderamente ha aumentado es el peso de la integración precaria, que pasa del $35 \%$ al $44 \%$ de la población. La exclusión, por tanto, crece, pero sobre todo lo hace la precariedad y la vulnerabilidad. En términos de población, señalan los autores, estaríamos hablando de más de ocho millones de personas afectadas por procesos de exclusión y más de diez millones bajo el umbral de la pobreza en 2009.

Particular interés tiene el análisis de los itinerarios de las personas encuestadas en las

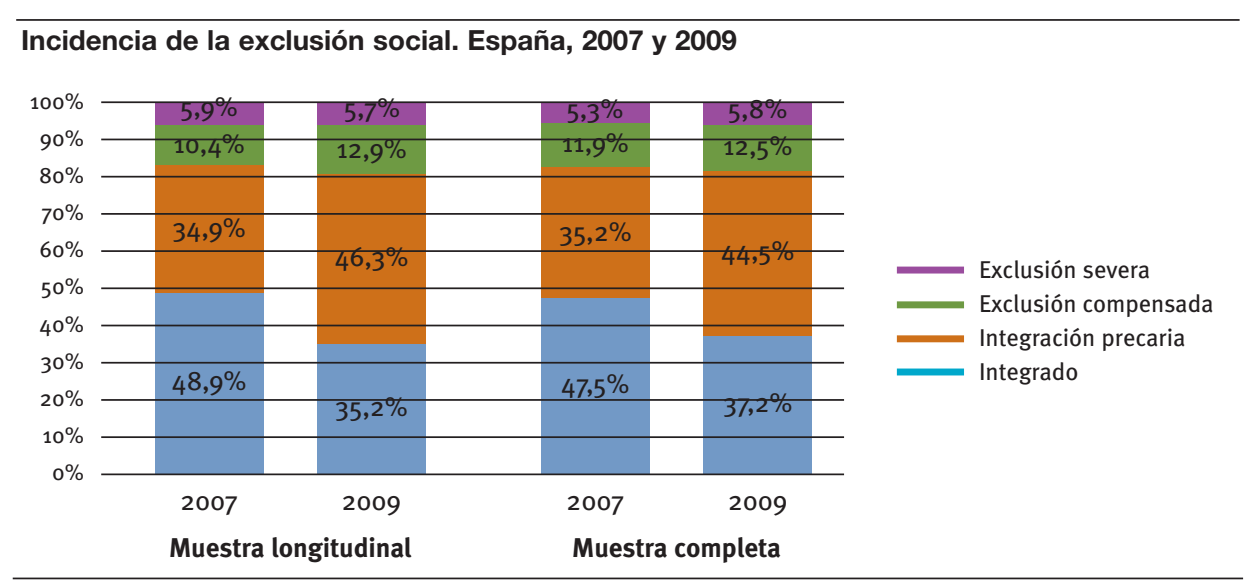

dos oleadas de la investigación, en la medida en que pone de manifiesto intensos procesos de movilidad, no siempre descendentes. En efecto, el $58 \%$ de los hogares de la muestra experimentan algún cambio en su situación; dentro de ese grupo, un $37 \%$-en torno al $21 \%$ de la muestra analizada en las dos olas- ha experimentado cambios positivos; y un $62 \%$-casi un tercio de la población-, cambios negativos, pasando de la integración a la precariedad, de la precariedad a la exclusión compensada o de ésta a la exclusión severa. En cualquier caso, sin tomar en cuenta los cambios dentro del espacio de la inclusión o de la exclusión (por ejemplo, las transiciones de la integración plena a la integración precaria), el estudio divide a la población analizada en 2007 y 2009 en cuatro grandes grupos: el de la integración estable, que supone el $70 \%$ de la población; el de las personas que protagonizan procesos de integración (10,6\%); el de las caídas en la exclusión (bien desde la integración, bien desde la precariedad, un $12,7 \%$ ); y el de quienes continúan viviendo en la exclusión continua $(5,8 \%$ de la población). El resumen de estos cambios se refleja en dos datos: el $27 \%$ de los hogares españoles habría pasado en estos dos años de una situación de integración plena a experimentar alguna situación de precariedad o de exclusión, mientras que apenas un $14 \%$ habría pasado de alguna de esas situaciones a la integración plena.
Otro capítulo de interés del informe es el que analiza el papel que han jugado los diferentes sistemas de ingresos mínimos para hacer frente a la nueva situación provocada por la crisis económica. A partir de los datos de la encuesta, no siempre coincidente con la información administrativa disponible, Miguel Laparra pone de manifiesto que, por una parte, las prestaciones económicas públicas (y en especial, las prestaciones canalizadas desde los servicios de empleo y de servicios sociales, que han multiplicado por 2,6 en este lapso los recursos distribuidos) han ayudado a compensar en parte la reducción de ingresos provenientes del mercado de trabajo, incluso en los sectores más excluidos. Sin embargo, esa redistribución económica no ha beneficiado preferentemente a los sectores más desfavorecidos, al contrario, y ha resultado insuficiente para evitar el incremento de la población en situación de precariedad y de exclusión. De hecho, según el estudio, la parte de la protección social más orientada a responder a las nuevas necesidades que generaba la crisis ha venido a concentrarse en las capas intermedias de la sociedad, caracterizadas por la precariedad y la exclulos beneficiarios de estas prestaciones se ubicaban en la precariedad integrada y la exclusión compensada, en 2009 el porcentaje llegaba al $75 \%$. sión moderada: si en 2007 dos tercios de 


\section{¿Por qué muchos menores permanecen largos intervalos de su vida en acogimiento residencial?}

El presente informe, elaborado por el reconocido grupo de investigación sobre familia e infancia de la Universidad de Oviedo, coordinado con Aldeas Infantiles SOS, estudia los factores que determinan el uso tan intensivo que se hace en España del acogimiento residencial, así como las razones que hacen que muchos niños y niñas permanezcan durante largos periodos en hogares y centros de protección.

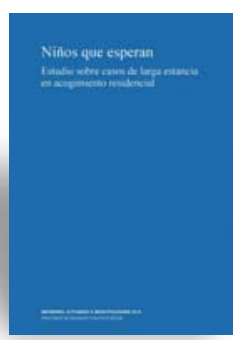

LÓPEZ, M. ET AL.

NIÑOS QUE ESPERAN. ESTUDIO SOBRE CASOS DE LARGA ESTANCIA EN ACOGIMIENTO RESIDENCIAL. SERIE: INFORMES, ESTUDIOS E INVESTIGACIÓN, MADRID, MINISTERIO DE SANIDAD Y PolítICA SOCIAL, 113 PÁGS. 2010. REF. 193501.

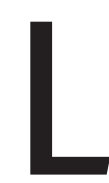

a Ley Orgánica 1/96, de Protección Jurídica del Menor, y la Ley 21/87, de Reforma del Código Civil, establecieron como principio básico la crianza del niño en un contexto familiar. En este sentido, el acogimiento residencial debe considerarse un recurso de transición y el acogimiento en familias, el recurso preferente. Sin embargo, el paso de los años ha puesto de manifiesto el escaso desarrollo de programas de acogimiento familiar. Esta investigación busca determinar el tipo de menores que permanecen durante largos periodos en centros residenciales, los procesos de intervención en que se encuentran inmersos, y los obstáculos que han hecho que el acogimiento familiar o la adopción no sean prioritarios.

La muestra objeto de estudio se compuso de 238 menores de siete comunidades autónomas. Eran niños y niñas menores de doce años que llevaban en acogimiento residencial más de un tercio de su vida. La recogida de datos se realizó a través de 104 profesionales de atención directa, 86 técnicos de infancia y 48 coordinadores o directores de centros residenciales, que completaron un cuestionario diseñado ad hoc-sobre los niños en acogida, la familia de origen y el proceso de protección-. Además, un panel de expertos analizó la información obtenida, debatió acerca de su significado y propuso implicaciones para la práctica.
En relación a las características de los niños, los datos señalan que se trata de menores cuya media de edad de ingreso en el hogar de acogida actual es de 4,6 años. Un 60\% del total nunca ha cambiado de hogar, y la mayoría de los que han residido en más de un centro solamente conocen dos hogares, lo cual indica que estos centros son un recurso de protección de gran estabilidad. Por edades, los menores de entre 9 y 12 años son los más numerosos, y el grupo de expertos indica que, a partir de esa edad, los procesos de mutua adaptación entre niños y familias se complican enormemente. En este sentido, los expertos recomiendan evitar que los niños alcancen esas edades en acogimiento residencial, ya que la probabilidad de retorno a sus familias disminuye; ésta podría ser una de la causas del estancamiento en el centro residencial. Por otra parte, los datos muestran que los niños que permanecen en acogimiento residencial durante demasiado tiempo presentan numerosos problemas que afectan a su salud, desarrollo, adaptación y rendimiento escolar. Los autores señalan que la falta de evaluaciones rigurosas en el momento del ingreso y a lo largo de la estancia no permiten afirmar que el origen de estos problemas sea el acogimiento, pero sí se sugieren esa posibilidad.

Con respecto a las características del contexto familiar, los datos muestran que las problemáticas psicosociales que presentan los padres y las madres son variadas y muy severas. Un $25 \%$ de los padres presentan graves problemas económicos; un $27 \%$, alcoholismo; un $24 \%$, drogodependencias; un $18,4 \%$ ha estado en prisión; un $16,2 \%$ tiene problemas de delincuencia; y un $11 \%$, de salud mental. En el caso de las madres, los problemas económicos $(35,9 \%)$ se dan en mayor medida, y los trastornos de salud mental $(24,7 \%)$ y la discapacidad intelectual $(22,1 \%)$ también son más frecuentes. Asimismo, es importante señalar que un $38 \%$ ha sido víctima de violencia de género. A juicio de los autores, la alta incidencia de problemas de salud mental y discapacidad intelectual en las madres es un gran reto para la intervención. Se trata de casos en los que la vinculación entre madre e hijo es muy fuerte, pero 
las dificultades para aprender y ejercer pautas de crianza y educación son considerables. En estos casos, los servicios no suelen optar por la separación definitiva, pero el pronóstico de reunificación es altamente improbable. Los autores concluyen que sería interesante aplicar un plazo máximo de dos años (tal como se establece en la Ley 54/2007, de Adopción Internacional) como la herramienta idónea para evitar que las estancias en acogimiento residencial se prolonguen demasiado en el tiempo.

Por lo que se refiere a las características del proceso de intervención, los datos muestran, en la línea de otros estudios, que la negligencia física es el motivo de la intervención en un amplio número de casos $(49,5 \%)$, seguido de la negligencia emocional (41,4\%), el imposible cumplimiento $(18,7 \%)$, el maltrato físico $(15,2 \%)$ y el abuso sexual en menor medida (3\%). En relación a la actitud de los progenitores, la madre se muestra cooperativa en solamente una cuarta parte de los casos (23,8\%), siendo lo más frecuente que su actitud sea ambigua (28\%) o bien de oposición (27,5\%). Los autores concluyen que esa ambigüedad materna puede despertar dudas en los profesionales a la hora tomar decisiones y llevarles a descartar el acogimiento familiar o la adopción como medidas prioritarias. Además, se señala que otro posible motivo que hace que las medidas de acogimiento residencial se prolonguen es la valoración positiva que los técnicos realizan de este recurso.

Este trabajo tiene implicaciones importantes para la práctica de los servicios de protección infantil. En primer lugar, los autores plantean la necesidad de clarificar el plan de caso, de adaptarlo a la situación real de la familia y a los recursos existentes, y de revisarlo frecuentemente. Asimismo, se recomienda mejorar la oferta de recursos existentes, potenciar el acogimiento en familia ajena, ofrecer más apoyos a los acogimientos en familia extensa, potenciar acogimientos de carácter permanente, introducir la posibilidad del acogimiento profesionalizado, aumentar los acogimientos y adopciones especiales para casos de mayor dificultad, y promover
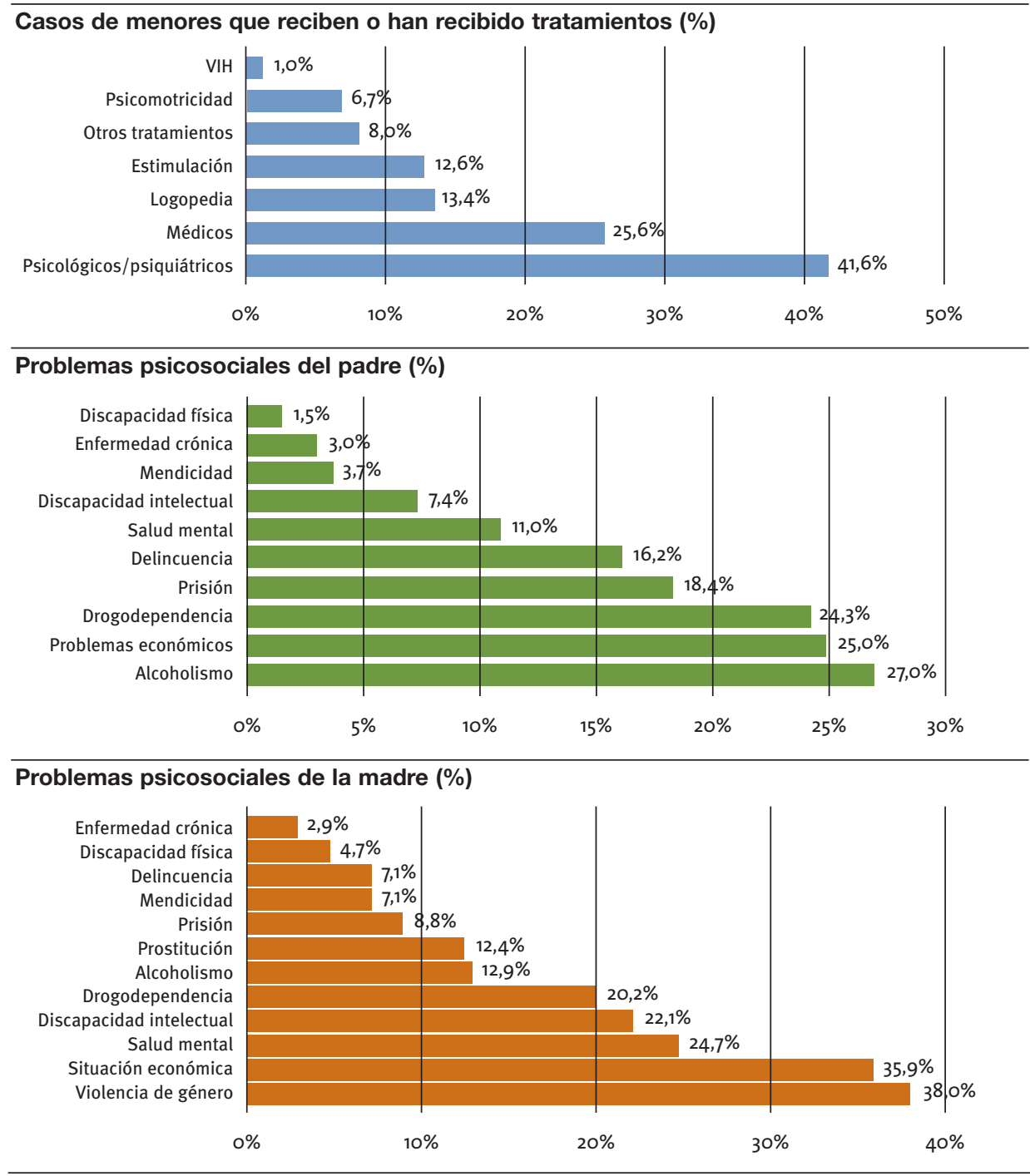

que los grupos de hermanos permanezcan juntos. Por otro lado, los autores solicitan optimizar los procesos de reunificación familiar, aumentar y potenciar los programas de apoyo a familias, incrementar los seguimientos y tratamientos, y establecer un plazo de dos años como tiempo razonable de espera para la recuperación de una familia. Otra de las recomendaciones que hace el estudio es la de formar a los técnicos para que asuman criterios que permitan tomar de decisiones en el supremo interés del menor cuando éste entre en conflicto con los intereses de los padres. En este sentido, se aboga por contar con manuales de procedimiento con criterios concretos y sus formas de aplicación. Por último, se reivindica un sistema de evaluación de resultados que permita saber qué efectos - positivos y negativos- está causando el acogimiento residencial. 


\section{El apoyo social a los sistemas de protección a las personas desempleadas y sin recursos en Europa}

Este estudio de opinión pública analiza el apoyo social en quince países europeos a tres de las políticas más significativas del Estado de bienestar. En el capítulo que aborda el apoyo social a los sistemas de protección a las personas desempleadas y sin recursos, el estudio pone de manifiesto que, frente a lo que pudiera pensarse, estos sistemas gozan de un amplio respaldo social. Este apoyo, sin embargo, se encuentra mucho más polarizado en aquellos países que cuentan con altas tasas de paro y un modelo de protección limitado.

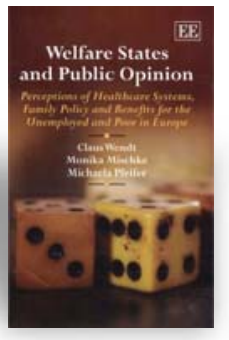

WENDT, C. ET AL.

Welfare States and Public Opinion.

Perceptions of Healthcare Systems, FaMily POLICY AND BENEFITS FOR THE

UnEMPLOYED AND POOR IN EUROPE.

Cheltenham, EdWARd Elgar, 200 PÁGS., 2011. REF. 196187. os sistemas de protección al desempleo y los de rentas mínimas tienen como finalidad cubrir la pérdida de ingresos y evitar las situaciones de pobreza de aquellas personas que no pueden acceder al mercado laboral. Sin embargo, y pese a que ambos son esenciales para prevenir la exclusión social y, por tanto, un pilar fundamental del Estado de bienestar, a menudo suele considerarse que gozan de menos apoyo social que otros sistemas, como el de salud o pensiones. Las razones que se esgrimen son diversas, pero fundamentalmente aluden, por una parte, a la desigual naturaleza de los riesgos que cubren y, por otra, a la relación que existe entre las contribuciones al sistema y los beneficios que ofrece, es decir, a su diseño institucional. Tampoco dentro del sistema de protección social se perciben de la misma forma la prestación por desempleo que el subsidio o la renta básica. En el primer caso, por ejemplo, la contingencia cubierta afecta a una mayor proporción de personas, para recibirla es necesario haber cubierto un periodo mínimo de cotización y, por su carácter contributivo, suele percibirse a menudo como una prestación 'debida'. En el caso de las rentas mínimas, en cambio, estas condiciones varían: son prestaciones no contributivas, financiadas a través de los impuestos y dirigidas a personas con bajos ingresos, sobre las que socialmente recaen mayores suspicacias sobre su 'merecimiento'. En la medida en que estas prestaciones se asientan sobre un sistema institucional que enfatiza la diferencia entre las personas que, con sus impuestos, contribuyen a él, y aquellas que se benefician de él, las posibilidades de que este sistema reciba un apoyo social mayoritario son, para los autores de este estudio, menores, y no hacen sino poner de manifiesto la importancia que los factores institucionales tienen en el apoyo o respaldo de la ciudadanía hacia las políticas sociales.

Precisamente sobre esta cuestión trata el presente estudio. En él, un nutrido grupo de investigadores alemanes abordan el respaldo social que tienen las políticas sociales en quince países europeos. Basándose en la premisa de que los factores de tipo institucional ejercen una influencia decisiva en la configuración de la opinión pública, el libro destina sendos capítulos al análisis de las actitudes sociales respecto tres ámbitos concretos: los sistemas de salud, de protección a la familia y de protección social dirigidos a personas desempleadas y sin recursos. Merece la pena subrayar que no se trata de un estudio de opinión pública al uso, ya que en él se combina un examen pormenorizado de la estructura institucional de cada país y de las variables macro más significativas con el de las actitudes sociales hacia cada uno de los tres sistemas mencionados. El resultado es un completo estudio en el que sus autores no sólo analizan las diferencias existentes entre países -para lo cual proponen, en cada capítulo, un conjunto de tipos ideales, según su diferente composición institucional- sino, también, las divergencias que, dentro de cada país, sostienen diferentes grupos sociales a la hora de respaldar o apoyar estos sistemas. Dada la profundidad con que estas cuestiones son abordadas en cada uno de los tres capítulos centrales del libro y, debido a su mayor interés en el ámbito que nos ocupa, se analizan en esta reseña los principales resultados del capítulo que aborda el apoyo social a los sistemas de protección dirigidos a personas desempleadas y con escasos recursos.

Una de las principales conclusiones que pueden extraerse de este capítulo es que el 
respaldo social a los sistemas de protección al desempleo y de rentas mínimas resulta más generalizado de lo que en un principio se podría pensar. Para los autores de este estudio, este hecho se debe, en buena medi$\mathrm{da}$, a la influencia que ejercen en la formación de la opinión pública valores con un fuerte arraigo, como la solidaridad o la justicia social. Pese a todo, también subyacen otros cálculos de tipo individual, mediatizados muy posiblemente, y según los autores, por factores de tipo institucional. Para llegar a esta conclusión, el estudio analiza tres variables (cfr. tabla): el grado de responsabilidad atribuida al Estado en la provisión de prestaciones básicas para las personas desempleadas y con escasos recursos, la evaluación del gasto en prestaciones sociales, y la disposición a pagar más impuestos para mejorar la situación de las personas con menos recursos. El análisis se completa con la selección de diversos indicadores macroeconómicos y con la elaboración de una tipología precisa de países.

En lo que se refiere al análisis de cada una de las variables de opinión seleccionadas, un primer vistazo a los resultados por países revela ya un elevado apoyo en todos ellos a que sea el Estado el responsable de proveer prestaciones sociales y de desempleo adecuadas. Asimismo, resulta también notable la disposición por parte de la ciudadanía europea a pagar más impuestos, mientras que las opiniones en torno al gasto social, es decir, a si éste debe recortarse o ampliarse, apenas pueden considerarse concluyentes. Los resultados del estudio también ponen de manifiesto que, mientras que la tasa de desempleo guarda una relación directa con la demanda de una mayor responsabilidad del Estado, la generosidad de las prestaciones por desempleo y de las rentas mínimas se relaciona de forma indirecta con la responsabilidad atribuida al Estado y la disposición a pagar más impuestos. Así, aquellos países que son más generosos con la dotación de sus prestaciones tienden a mostrar una menor disponibilidad a pagar más impuestos y tienden también, en menor medida que el resto, a demandar del Estado una mayor responsabilidad. Si bien este

\begin{tabular}{lccc}
\hline \multicolumn{4}{c}{ Actitudes sociales hacia las prestaciones sociales y por desempleo. 2001 (\%) } \\
$\begin{array}{l}\text { Responsabilidad } \\
\text { del Estado }\end{array}$ & $\begin{array}{c}\text { Evaluación } \\
\text { del gasto }^{2}\end{array}$ & $\begin{array}{c}\text { Disposición a pagar } \\
\text { más impuestos }^{3}\end{array}$ \\
\hline Austria & 3,41 & 2,90 & 3,57 \\
\hline Bélgica & 3,99 & 3,05 & 3,50 \\
\hline Dinamarca & 3,68 & 3,22 & 3,82 \\
\hline Finlandia & 4,28 & 3,25 & 3,94 \\
\hline Francia & 4,02 & 3,01 & 3,22 \\
\hline Alemania & 3,62 & 2,81 & 3,71 \\
\hline Grecia & 4,61 & 3,73 & 3,84 \\
\hline Irlanda & 4,27 & 3,45 & 3,72 \\
\hline Italia & 3,98 & 3,43 & 3,69 \\
\hline Países Bajos & 3,71 & 3,38 & 3,94 \\
\hline Portugal & 3,92 & 3,24 & 3,80 \\
\hline España & 4,14 & 3,51 & 3,90 \\
\hline Suecia & 3,77 & 3,33 & 3,51 \\
\hline Reino Unido & 3,87 & 3,49 & 3,67 \\
\hline Media & 3,95 & 3,27 &
\end{tabular}

Nota: las medidas expresan valores que van desde 1 (muy en desacuerdo) hasta 5 (muy de acuerdo).

1. Variable sintética que mide el grado de acuerdo con la responsabilidad atribuida al Estado en la provisión de prestaciones para personas desempleadas y con escasos recursos (prestaciones y subsidios por desempleo adecuados y renta básica garantizada). 2. Expresa el grado de acuerdo con la siguiente afirmación: "El Estado debería gastar más en prestaciones para las personas pobres". 3. Expresa el grado de acuerdo con la afirmación: "Estaría dispuesto a pagar más impuestos si los recursos se utilizaran para mejorar la situación de las personas pobres". Fuente: Eurobarómetro 56.1.

hecho podría prestarse a varias lecturas, los autores del estudio lo atribuyen a un efecto de 'saturación', según el cual en los países con prestaciones más generosas -que son también los que soportan una mayor carga fiscal- es común la convicción de que las necesidades están suficientemente cubiertas y que, por tanto, no es necesaria ni una mayor responsabilidad pública, ni mayores impuestos.

Los resultados del estudio resultan también del máximo interés cuando se analizan utilizando la tipología de países diseñada. Así, en lo que respecta a la responsabilidad atribuida al Estado, los resultados obtenidos ponen de manifiesto que aquellos países con un sistema de protección más precario (grupo D) se muestran más proclives a una mayor responsabilidad púbica, mientras que la responsabilidad atribuida al Estado decre- ce en aquellos con un sistema de protección amplio y bajas tasas de desempleo (grupo A). Los datos también ponen de relieve cómo, curiosamente, y pese a contar con unos sistemas de protección muy limitados y las mayores tasas de desempleo, es en el caso de los países pertenecientes al grupo D (Grecia e Italia) donde la opinión pública se encuentra menos polarizada. Justo lo contrario ocurre en los países integrados en el grupo $\mathrm{C}$, caracterizados por altas tasas de desempleo estructural y unos niveles de gasto alto en prestaciones al desempleo y medio-bajo en rentas mínimas. En este grupo, pues, en el que se encontrarían España, Francia o Alemania, habría una mayor división en la opinión pública, siendo los grupos socioeconómicos más acomodados más proclives que los más desfavorecidos a un menor protagonismo de la responsabilidad pública en estas cuestiones. 


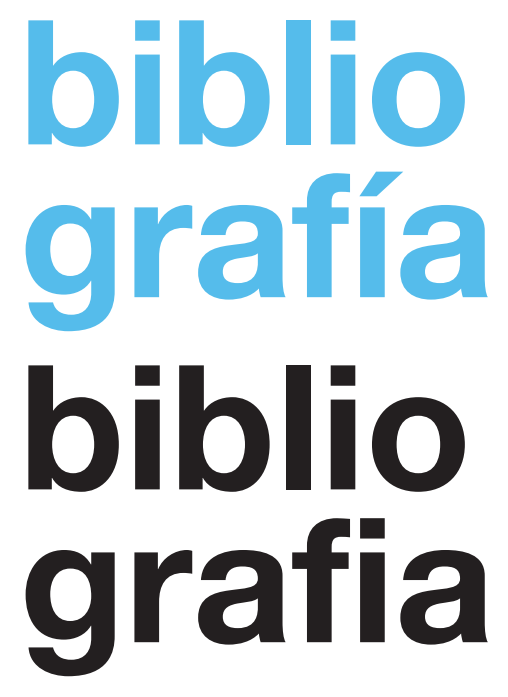

experiencias

inclusión

\section{Experiencias de participa- ción en servicios de inclusión}

\section{W.AA.}

LA PARTICIPACIÓN DE LAS PERSONAS COMO HERRAMIENTA PARA LA INCLUSIÓN SOCIAL. EXPERIENCIAS PILOTO EN ENTIDADES SOCIALES PARA EL FOMENTO DE LA PARTICIPACIÓN. BILBAO, REd EUROPEA DE LUCHA CONTRA LA PoBREZA Y LA EXCLUSIÓN SOCIAL EN EUSKADI, 68 PÁGS., 2010. REF. 196929.

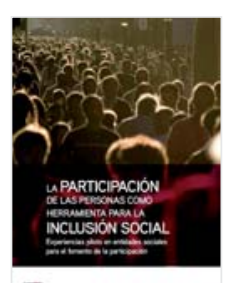

En los últimos años, la participación ciudadana se ha hecho un hueco en la agenda social. Hoy día casi

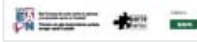
todos los pro-

yectos, servicios o programas disponen de algún mecanismo que permite a las personas beneficiarias expresar sus opiniones e ideas. Ahora bien, mientras que algunas iniciativas parecen diseñadas simplemente para cumplir el expediente, otras buscan en la participación una estrategia no sólo para ajustarse mejor a las necesidades reales de las personas destinatarias, sino para reconocer a éstas como protagonistas de la acción colectiva. A este segundo grupo pertenecen las experiencias de participación reunidas en este libro.

La obra es fruto del trabajo conjunto de siete entidades vascas pertenecientes a la Red Europea de Lucha contra la Pobreza y la Exclusión Social: Gizakia, Federación Sartu, Asociación Bizitegi, CEAR Euskadi, Asociación
Elkarbanatuz, Cáritas Bilbao y Asociación Zubietxe. Cada una de ellas ha reflexionado sobre el fomento de la participación de las personas en situación de exclusión a las que se dirigían sus servicios, en un ejercicio que tenía cinco objetivos: conocer los niveles de participación de usuarias y usuarios, sus necesidades a este respecto y sus percepciones sobre el proceso de incorporación social; evaluar la metodología utilizada con respecto a la participación de estas personas en esas oenegés; $y$, finalmente, establecer cauces para que las personas beneficiarias pudieran decidir si participan o no en las entidades.

Si bien cada oenegé plantea el análisis desde su propia actividad, las reflexiones se han elaborado en el marco de un proceso compartido de sistematización de la práctica iniciado en 2005 y que sigue en curso. Las conclusiones obtenidas apuntan a que el fomento de la participación de usuarias y usuarios en las entidades sociales debe comenzar a iniciativa de éstas, buscar la implicación de todos sus miembros y convertirse en una línea estratégica. Igualmente, es imprescindible dar voz a las personas excluidas, proponer y adecuar los cauces participativos a sus necesidades y capacidades, y asumir la negativa a participar como una forma más de participación en estas entidades. 
La regeneración urbanística, clave de un programa inglés de desarrollo local

\section{COLE, I. ET AL.}

INTERVENTIONS IN HOUSING AND THE Physical EnVIRonment in Deprived Neighbourhoods. Evidence from the New Deal for Communities Programme. LONDRES, DEPARTMENT FOR COMMUNITIES AND LOCAL GOVERNMENT, 139 PÁGS. 2010. REF. 188061.

\section{.

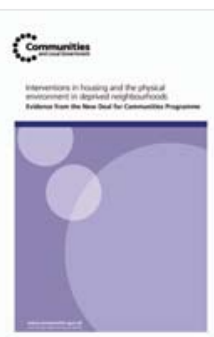 \\ New Deal for Communities es el nombre de un pro- grama de desarrollo local imple- mentado en Inglaterra entre 1999 y}

2008. La iniciativa tenía por objetivo mejorar las condiciones de vida en 39 barrios, donde residían alrededor de 9.800 personas, en total. Se trataba de un proyecto holístico de recuperación, que atendía tanto al entorno (criminalidad, comunidad, vivienda y urbanismo) como a las personas (educación, salud, desempleo), y en el que el Gobierno invirtió unos 50 millones de libras (casi 630 euros por persona/año, de media). El presente informe hace balance de dicho programa.

Las mayores inversiones (31\%) se realizaron en materia de vivienda y urbanismo, un ámbito que no se contemplaba en las primeras etapas del proyecto y fue incorporado más tarde, en respuesta a la demanda de los residentes. Gracias al programa, se construyeron o rehabilitaron casi 19.800 viviendas y se acondicionaron 96 edificios no residenciales. También mejoró la opinión del vecindario sobre sus viviendas y el entorno, se mantuvo la proporción de quienes deseaban mudarse a otro barrio (39\%) y aumentó el precio medio de las viviendas -el indicador más 'objetivo' del aprecio por estas zonas-. Las mejoras en las viviendas y en el entorno urbanístico aparecen como un factor clave del éxito del programa.

Entre las lecciones que el equipo investigador extrae de esta experiencia, cabe citar la necesidad de buscar un equilibrio entre las preferencias de la comunidad, habitualmente referidas a problemas inmediatos, y las del mercado inmobiliario, más preocupado por la sostenibilidad. También resulta fundamental coordinar los esfuerzos de los distintos agentes, actuar con pragmatismo, y ceñirse a los recursos disponibles y a las competencias asignadas a cada actor. Los autores se muestran razonablemente contentos con los resultados alcanzados, pero reclaman la continuidad de las políticas descritas, dado que el triunfo o fracaso de este tipo de intervenciones se decide a largo plazo.

\section{derechos}

discapacidad

\section{Vulneración de derechos de personas con discapacidad}

Comité ESPAÑol de REPRESENTANTES DE

PERSONAS CON DISCAPACIDAD

DERECHOS HUMANOS Y DISCAPACIDAD.

INFORME ESPAÑA 2010. MADRID, COMITÉ

EsPañol de Representantes de PERSonas CON DISCAPACIDAD, 83 PÁGS., 2011.

REF. 196019.
El presente trabajo, elaborado por el Comité Español de Representantes de Personas con Discapacidad (CERMI), versa sobre la aplicación de la Convención Internacional sobre los Derechos Humanos de este colectivo. Al igual que en ediciones anteriores, en esta ocasión las fuentes han sido consultas $y$ denuncias de vulneración de derechos de personas con discapacidad ante el CERMI, la información proporcionada por diferentes asociaciones colaboradoras y algunas noticias publicadas en prensa. El documento analiza en profundidad el respeto a los artículos de la Convención, las vulneraciones detectadas a lo largo de 2010, la acción positiva por parte de la Administración y algunas resoluciones judiciales, a la par que plantea numerosas recomendaciones al respecto.

Entre las principales conclusiones del informe, se señalan las vulneraciones ocasionadas por la existencia de un conflicto entre la legislación española y la Convención, la ausencia de perspectiva de derechos humanos en la normativa sobre discapacidad y las violaciones de derechos causadas por la desigualdad de oportunidades. De manera específica, los autores destacan la falta de un verdadero enfoque de derechos humanos del Sistema para la Autonomía y Atención a la Dependencia (SAAD), un amplio de desarrollo de prestaciones de tipo asistencialista y un escaso desarrollo de las prestaciones orientadas a la promoción de la autonomía personal, a la vida independiente y a la inclusión social. envejecimiento inclusión

\section{Personas mayores y nuevas} tecnologías

Del Arco, J. y SAn Segundo, J. Ma (COORDS.)

LOS MAYORES ANTE LAS TIC. ACCESIBILIDAD Y ASEQUIBILIDAD. MADRID, FUNDACIÓN REF. 192181.

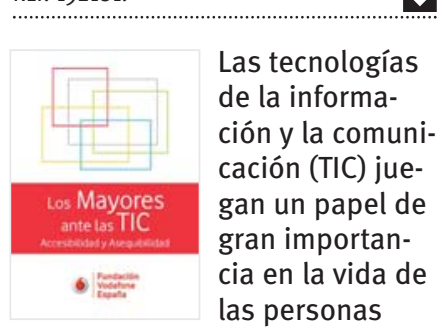

mayores y pueden incrementa su calidad de vida y autonomía personal. Los principales obstáculos de acceso a las TIC a los que tiene que hacer frente este colectivo son el elevado precio de los productos, su cuestionada utilidad y la falta de conocimiento sobre la oferta de mercado. El presente trabajo realiza un análisis pormenorizado de la actitud y el uso que las personas mayores hacen de las nuevas tecnologías. La realización de este informe ha permitido identificar barreras y actitudes favorables frente al uso de las TIC, así como tecnologías que las personas mayores desean utilizar.

En la primera parte del documento se presenta una primera valoración de los principales indicadores existentes a escala estatal e internacional sobre el acceso de las personas mayores a las TIC. En segundo lugar, se analiza la magnitud de las diferencias entre el uso que las personas mayores hacen de las TIC 
respecto al del conjunto de la población, así como respecto a otros países de la Unión Europea. Por último, a través de la valoración del efecto de diferentes variables en el acceso a dos de las tecnologías predominantes -la telefonía móvil e Internet-, se identifica el origen de las principales diferencias, que se plasman no sólo en el nivel de utilización, sino en los productos y servicios más empleados.

\section{discapacidad infancia}

\section{Emancipación de jóvenes con distrofia muscular de Duchenne}

\section{ABBotT, D. y CARPENTER, J.}

Becoming an AdULt. TRANSition FOR

Young Men with Duchenne Muscular DYSTROPHY. BRISTOL, UNIVERSITY OF BRISTOL, 45 PÁGS., 2010. REF. 194192.

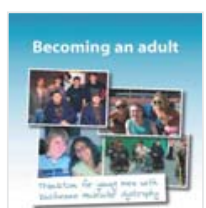

El presente trabajo analiza la transición a la edad adulta de jóvenes con distrofia muscular de Duchenne, identifica algunos de los problemas a los que tienen que hacer frente y propone recomendaciones para jóvenes, familiares y profesionales clave en la intervención. La metodología empleada en este estudio consistió en la distribución postal de un cuestionario a un total de 38 padres y madres, así como en la realización de entrevistas individuales a 40 jóvenes y a sus familiares. Entre las principales conclusiones, se señala una ausencia alarmante de ejemplos de planificación formal de la transición de estos jóvenes a la edad adulta. Así, solamente una de cada cuatro familias cuenta con un gestor de casos o un trabajador social responsable de su caso. Además, se indica que seis de cada diez padres y madres no cuentan con suficiente información sobre los posibles servicios a los que sus hijos pueden optar a corto plazo. En lo que concierne a educación y trabajo, la mitad de los jóvenes entrevistados dice acudir a un colegio y sus familiares informan de la dificultad de encontrar un centro que satisfaga las necesidades específicas de su caso. Con respecto a la escolarización, se identifican problemas de accesibilidad y participación de estos jóvenes en actividades extracurriculares. El informe pone de manifiesto que los jóvenes que continúan escolarizados cuentan, en general, con una vida social adecuada y con suficiente número de amigos. Sin embargo, quienes ya han abandonado la escuela viven de manera más excluida, tienen menos amistades y las actividades en el exterior las realizan en exclusiva con familiares cercanos.

\section{inclusión \\ familia}

\section{Familias separadas, puntos de encuentro y visitas supervisadas}

Sellenet, C.

LES VISITES MÉdiatisées POUR des faMilLES Séparées. Protéger l’enfant. París,

L'HARMATTAN, 223 PÁGS., 2010.

REF. 194838.

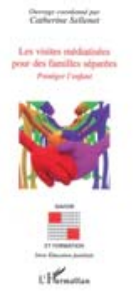

La ruptura conflictiva entre los progenitores, el encarcelamiento, la hospitalización o la enfermedad mental de alguno de ellos, así

como la tutela judicial del menor pueden dificultar el contacto regular entre niños/as, madres y padres, que, si resulta seguro para el menor, le beneficia enormemente. Pero, ¿cómo garantizar el ejercicio de ese derecho en circunstancias tan difíciles como las descritas? Un grupo multidisciplinar de profesionales y especialistas universitarios debatieron esta cuestión en un coloquio celebrado en Francia en 2008. Once comunicaciones allí presentadas se recogen en este libro de la editorial L'Harmattan, que, por su variedad de enfoques, proporciona una visión transversal del tema estudiado.

La obra pone de manifiesto la necesidad de dispositivos de mediación que faciliten esas reuniones familiares. Esto no obsta, sin embargo, para señalar sus limitaciones -tales como la pérdida de espontaneidad e intimidad-o cuestionar el carácter neutral que se les presupone a los puntos de encuentro. Lo que se comparte en ellos se considera, en cualquier caso, fundamentales a la hora de establecer, mantener y consolidar los vínculos entre niños/as y progenitores. El libro examina una amplia casuística de menores separados de sus padres 0 madres, interesándose por los mecanismos que regulan los vínculos parentofiliales y el tipo de intervenciones más adecua- das para -según convengafomentarlos, preservarlos o reelaborarlos.

\section{políticas \\ sociales \\ investigación \\ y evaluación}

\section{Manual universitario de psicología social}

HOGG, M. A. Y VAUGHAN, G. M.

Psicología social. MAdRID, EdITORIAL MÉdica Panamericana, 648 PÁGS., 2010. REF. 187307.

$\begin{array}{ll}\text { Psicología } & \begin{array}{l}\text { La psicología } \\ \text { social forma } \\ \text { parte de los } \\ \text { planes de } \\ \text { estudial de } \\ \text { numerosas } \\ \text { carreras uni- } \\ \text { versitarias. } \\ \text { El alumnado } \\ \text { que se }\end{array}\end{array}$

enfrente a esta materia por primera vez durante el curso que ahora comienza encontrará en esta obra un completo y bien pensado manual. Son más de 700 páginas, en las que los autores han recogido los fundamentos de la disciplina, anteponiendo los temas y las investigaciones más cercanos al contexto intelectual, cultural y educativo europeo sobre los procedentes de Estados Unidos, donde la psicología social ha conocido un gran desarrollo. De esta manera, han elaborado un volumen que, a su juicio, responde a los intereses y las experiencias de la audiencia a la que va dirigido.

Esta quinta edición revisada y actualizada del libro conserva 
de sus predecesoras el enfoque histórico en la exposición, el énfasis en la terminología de la disciplina, las referencias cruzadas y el engarce entre teoría básica e investigación aplicada, dos aspectos que, con cierta frecuencia, aparecen disociados en los manuales. El primer bloque de contenido analiza el modo en que la alteridad aparece en las actividades y representaciones cognitivas del individuo, ahondando en la formación y el cambio de actitudes. Seguidamente, se estudian la influencia interpersonal y los procesos grupales, con apartados dedicados al prejuicio, la discriminación, el conflicto o la agresión. Las relaciones interpersonales (atracción, amistad, amor, altruismo), el lenguaje y la comunicación se abordan también en la obra, que se cierra con un capítulo dedicado al papel de la cultura en la psicología social. La obra se completa con una serie de anexos que incluyen una bibliografía, un glosario, e índices analítico y de autores, elementos estos últimos que facilitan la consulta rápida del volumen.

\section{políticas}

sociales

discapacidad

\section{Monográfico sobre trabajo social y discapacidad}

StAinton, T. et al. (EDS.)

SOCIAL WORK'S CONTRIBUTION TO DISABILITY POLICY AND PRACTICE AROUND THE WORLD. AUSTRALIAN SOCIAL WORK,

VOL. 63, № 1, 139 PÁGS., 2010. REF. 184433.

Por lo general, las personas con discapacidad deben superar

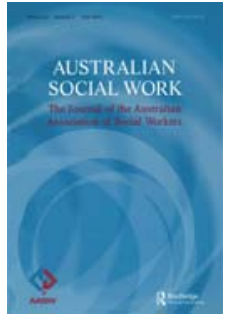

múltiples

barreras para participar en igualdad de condiciones en la sociedad. Tal circunstancia ha hecho de este grupo uno de los de los 'colectivos' a los que preferentemente se dirigen las intervenciones desde el trabajo social. En este contexto, cabe preguntarse hasta qué punto la praxis de las y los profesionales de la disciplina favorece la autonomía de estas personas 0 , por el contrario, contribuye a perpetuar su falta de oportunidades. Las contribuciones del presente monográfico de la Revista Australiana de Trabajo Social giran en torno a ese tema, e ilustran los desafíos que la atención a las personas con discapacidad representa tanto para las políticas sociales como para la práctica y la investigación en trabajo social.

El número incluye varios estudios de caso que reflexionan sobre la atención que las y los profesionales de esta disciplina han ofrecido a grupos específicos de personas con discapacidad. Fijándose en esas profesionales, otro de los estudios analiza las similitudes del papel que las trabajadoras sociales anónimas han jugado en el terreno de la discapacidad en el Reino Unido y en Australia. La manera de legitimar el trabajo social en el terreno de la discapacidad y de reforzar la praxis basada en los derechos humanos es también objeto de estudio en estas páginas. Finalmente, se recoge una experiencia de investigación emancipadora en la que han participado jóvenes con síndrome de Down.

políticas

sociales

inclusión

\section{Retrato social europeo}

\section{EUROSTAT}

The Social Situation in the European

UNION 2009. BRUSELAS, COMISIÓN

EUROPEA, 364 PÁGS., 2010.

REF. 182145.

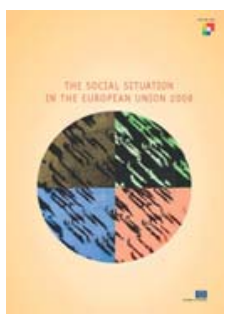

La Unión Europea edita cada año un informe sobre la situación social en los países miembros. Consta de una parte monográfica y otra donde se recogen estadísticas ya publicadas sobre diversos aspectos de las políticas sociales. La edición correspondiente a 2009 arranca con una síntesis de los resultados del Eurobarómetro que, a mediados de 2009, analizó el clima social de la UE, a partir de las opiniones de la ciudadanía respecto a diferentes indicadores de bienestar y protección social. En segundo lugar, y como tema monográfico, el documento analiza el panorama de la vivienda en Europa, examinando cuestiones como la accesibilidad y la calidad, los costes de mantenimiento, o la situación de las personas sin techo. Finalmente, el informe hace una revisión estadística comparativa de diecisiete áreas sociales: población, inmigración, familia, situación económica general, educación, for- mación a lo largo de la vida, empleo, paro, políticas de mercado de trabajo, protección social, pensiones, distribución de la renta, pobreza, privación material, salarios e ingresos de hombres y mujeres, esperanza de vida y salud, y accidentes de trabajo y carretera.

\section{atención \\ comunitaria \\ discapacidad}

\section{Erresuma Batuko etxebizitza} sozialak eta buruko osasuna

Pleace, N. eta Wallace, A.

Demonstrating the EfFectiveness of Housing Support Services for People with Mental Health Problems: A Review.

Heslington, Centre for Housing Policy, 81 OR., 2011. ERREF.: 194480.

York Unibertsitateko txosten honen arabera, oso garrantzizkoa da buruko nahasdurak edota bestelako buruko osasun arazoak dituztenentzat Erresuma Batuko gizarte-laguntzako etxebizitzak lortzeaz arduratzen diren elkarte eta bestelako zerbitzuek eskainitako aukerak indartzea. Buru osasuna hobetzen laguntzen die, eta asko hobetzen da berauen independentzia, ongizatea eta gizarteratzea. Aditu batzuen arabera, probatan jasotako ebidentzia gutxi omen dago gaiaren inguruan, eta esfortzuak eskatzen dituzte babes sozialeko etxeak kolektibo honen hobekuntzarako gerta daitezen. Izan ere, gizarte-laguntzako etxebizitzak eraginkortasun gehiago izan omen dezake, besteak beste, zaintzarako prozesuen baitan; adibidez, zaintza egoiliarren 
aurrean, eta, batik bat, egoitzak urrutiegi dauden kasuetan.

Azterlan honetan, berrikusi egin dira egun eskura dauden eta erabiltzen diren neurri eta baliabide eraginkorrak. Horretaz gain, txostenak iradokitzen du proba-banku bilakatzeko metodologia garatzea, eta horren bidez gidatzea etorkizunean egingo diren ikerketa eta ebaluazioak. Deliberamenduetan jasotakoaren arabera, hainbat adierazle eta emaitza aurkitu dituzte egindako berrikustean, baina askotarikoak dira eta zailak kategorietan osatzeko. Jasotako ebidentzietan,

Erresuma Batuaren eta Europako datuak urriagoak dira AEBkoen aldean. Hala ere, Ameriketan etxerik gabeko buruko nahasdura larriak dituzten pertsonentzako zerbitzuak izaten dira ohikoenak.

\section{prestaciones \\ económicas}

envejecimiento

\section{Banakako laguntza ekono- mikoak, gizarte-zerbitzuen erabiltzaileentzako panazea?}

\section{LYMBERY, M.}

A NEW VISION FOR ADULT SOCIAL CARE? CONTINUITIES AND CHANGE IN THE CARE OF older people. Critical Social Policy, 3O. BOL., 1. ZENB., 5-26 OR., 2010. ERREF.: 183925.

Ingalaterran, Europako beste herrialde askotan bezala, eguneroko eginbeharretarako laguntza behar duten pertsonei, zerbitzuak eskaini ordez, laguntza ekonomiko bat jasotzeko aukera zabaldu zaie, ordainketa zuzena (direct payment) edo banakako aurrekontua (personal budget) bezala ezagutzen diren programen bitartez. Programa hauek martxan jartzearen helburu nagusiak -Gobernuak argitaratutako dokumentu zuzentzaileen araberaerabiltzaileen hautua sustatzea, prebentzioa indartzea, zerbitzu komunitarioetarako sarbidea hobetzea eta baliabide publikoen erabilpen eraginkorragoa egitea dira. Izan ere, zerbitzuak eskaini ordez diru-laguntzak emanez gero, erabiltzaileek arreta beren nahietara hobeto egokitu eta diru publikoari ahalik eta etekinik handiena aterako diotela espero da. Era berean, sistemak zerbitzuen antolaketa eta kudeaketarako erabiltzen dituen baliabideak ere aurreztea lortzen da.

Critical Social Policy aldizkari prestigiotsuan argitaraturiko artikulu honen arabera, ordea, Gobernuak gehiegizko optimismoz heldu dio laguntza ekonomikoen bideari, haien diseinuan, desio diren helburuak lortzeko beharrezkoak diren elementu guztiak presente diren kontutan izan gabe, eta arreta eskaintzeko formula berri honek gizarte-zerbitzuen sisteman izan ditzakeen ondorio filosofiko eta praktikoen inguruko hausnarketa nahikorik egin gabe. Autorearen ustez, lehenik eta behin, garatutako politikek ez dute nahikoa oinarri enpirikorik, izan ere, banakako laguntza ekonomikoen eraginkortasuna aztertu duten ikerketek emaitza positiboak lortu dituzten arren, oso lagin txikiekin eta erabiltzailemota zehatzekin burutu dira. Bestalde, politika hauen arazo nabarmenetako bat, autorearen ustez, aukeratzeko eskubidea babestua izateko eskubidearen gainetik jartzen duela da. Zentzu horretan, autoreak zalantzan jartzen du, Gobernuak suposatzen duen bezala, hiritar guztiak beren zaintza antolatzeko gai izan daitezkeenik, edo, are gehiago, ardura hori bere gain hartzeko prest egongo direnik. Azkenik, zerbitzuak ordezkatu eta diru-laguntzak eskaintzeko aukera justifikatzeko orduan, Gobernuak desgaitasunak dituzten pertsonen aldeko gizartemugimenduak aldarrikatzen duen 'bizitza independientea' eta antzeko kontzeptuak darabiltzan arren, indarrean jarritako neurriak kontsumismoaren bidetik doazela salatzen du autoreak, eguneroko bizitzan laguntza behar duten pertsonak eskubide-hartzaile kontsideratu ordez, kontsumitzaile soiltzat hartzen dituen neurrian.

\section{planificación y \\ regulación \\ inclusión}

\section{Plan de participación social de las personas con disca- pacidad en Bizkaia}

Departamento de Acción Social Plan para la Participación y Calidad de Vida de las Personas con Discapacidad EN BIZKAIA 2010-2013 / BIZKAIAN Gaigabezia Duten Pertsonen ParteharTzerako eta BizI Kalitaterako Plana 2010-2013. BILBAO, DiPUTACIÓN FORAL DE BIZKAIA, 74, 74 PÁGS., 2010. REF. 192290.

El objetivo del presente plan de la Diputación Foral de Bizkaia es mejorar el desempeño de las instituciones y entidades que participan en la atención y pro-

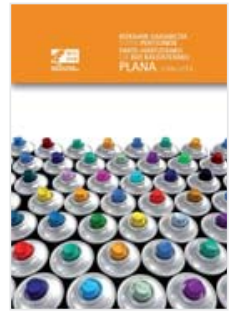

moción de las personas con discapacidad y sus familias, orientándolo hacia un modelo de participación y calidad de vida en comunidad. El Departamento de Acción Social busca conseguir que las personas y la sociedad puedan avanzar hacia una cultura de la autonomía individual y la vida independiente, que permita a todas las personas, sin exclusiones ni discriminaciones de ningún tipo, realizar sus propias elecciones y vivir en condiciones idóneas de calidad de vida y autorrealización.

Este documento es, básicamente, una guía sobre los recursos necesarios para atender a las personas con discapacidad y ha sido elaborado en colaboración con las entidades del tercer sector. En primer lugar, se identifica, caracteriza y ubica en el territorio a las personas con discapacidad y sus familias. En una segunda parte, se profundiza en la evolución de las necesidades de este colectivo, y finalmente, se presenta el mapa actual de prestaciones y servicios. Los programas de actuación que plantea este plan se basan en cinco ejes estratégicos de transformación social: vida autónoma en comunidad, inclusión y participación activa; accesibilidad universal, diseño para todos e igualdad de oportunidades; universalidad de los servicios sociales y equidad en el acceso; calidad y planificación centrada en la persona; y colaboración y diálogo con el tercer sector. 
investigación

y evaluación

profesionales

La mano de obra para atender a las personas mayores, ¿un bien que escasea?

RUBERY, J. ET AL.

The Recruitment and Retention of a Care WORKForCE FOR OLDER PEOPLE.

MANCHESTER, MANCHESTER BusinesS

SCHOOL, 426 PÁGS., 2011. REF. 195933.

Dos de los mayores problemas a los que se enfrentan quienes gestionan servicios de atención a personas mayores son el reto que supone encontrar profesionales cualificados $y$, una vez que se da con ellos, la dificultad de conseguir que sigan como empleados por mucho tiempo. Con el fin de identificar elementos que podrían facilitar tanto el proceso de reclutamiento como la retención del personal, el Departamento de Salud británico encargó este estudio al Centro de Investigación Europeo sobre Trabajo y Empleo (European Work and Employment Research Centre). La entidad llevó a cabo encuestas entre directores de servicios sociales, representantes de empresas proveedoras de servicios sociales y profesionales del ámbito de los servicios sociales. El análisis de las respuestas, que se completó con una revisión de la literatura reciente en la materia, ha dado como resultado este extenso informe de más de 400 páginas, sin duda, uno de los proyectos de investigación más ambiciosos realizados en Europa sobre el tema. Aunque está centrado en las características particulares del mercado de trabajo y de los servicios sociales en el Reino
Unido, muchas de las conclusiones son generalizables fuera de este contexto geográfico.

\section{investigación \\ y evaluación \\ envejecimiento}

\section{¿Cómo asegurar una buena calidad asistencial en las soluciones residenciales para personas mayores?}

GARWOOD, S.

A Better life for Older People With High SUPPort NeEdS IN Housing WITH CARE. YoRK, JOSEPH ROWNTREE FOUNDATION, 149 PÁGS., 2010. REF. 193759.

En 2009 La Fundación Joseph Rowntree presentó un nuevo programa, llamado Una Vida Mejor (A Better Life). Se trata de un proyecto que pretende investigar cómo mejorar la calidad de vida de las personas mayores con un grado de dependencia severa. En este documento, uno de los primeros publicados dentro del marco del programa, se estudia concretamente qué características deben reunir las viviendas asistidas para asegurar el bienestar del citado colectivo. Los aspectos de esta modalidad de vivienda que aquí se analizan son los siguientes: el acceso y la diversidad; la comunicación y la toma de decisiones; las actitudes hacia la discapacidad y la dependencia; y, por último, el personal. Los seis expertos que han participado en el estudio han llevado a cabo un análisis de la literatura reciente que arroja luz sobre estos temas. Después de presentar los resultados de esta revisión de la bibliografía, los autores emiten una serie de recomendaciones, útiles tanto para las personas mayores y sus familiares como para los profesionales que planifican y ejecutan estos servicios.

\section{investigación \\ y evaluación}

discapacidad

\section{El ambiente social del barrio como factor de riesgo para la depresión}

STAFFORD, M. ET AL.

NEIGHBOURHOOD SOCIAL ENVIRONMENT AND DEPRESSIVE SYMPTOMS IN MID-LIFE AND BEYOND. AGEING AND SOCIETY, VOL. 31 № 6, PÁGS. 893-910, 2011. REF. 196743.

Recientes estudios epidemiológicos ponen de relieve que los síntomas depresivos se dan con mucha frecuencia entre la población mayor. Se sabe, por otro lado, que la depresión puede afectar de forma negativa a la calidad de vida de las personas afectadas. Por ello existe un gran interés en identificar los elementos que actúan como factores de riesgo a la hora de contraer esta enfermedad. Esta investigación, realizada entre 7.500 personas que forman parte de la muestra del estudio longitudinal de envejecimiento de Inglaterra, analiza la posible influencia que puede ejercer el ambiente social del barrio donde viven sobre los síntomas de depresión. Se estudia, concretamente, de qué manera la cohesión social y la seguridad percibida inciden sobre la depresión. En este análisis se tiene también en cuenta el posible efecto mediador de la calidad de las amistades y la sensación de control de las personas encuestadas. Los resultados estadísticos ponen de relieve la existencia de una relación causal entre el ambiente social negativo y los síntomas de depresión. Parece, además, que el grado de cohesión social del barrio ejerce cierta influencia sobre la sensación de control y la percepción de la calidad de la amistad. Los autores no se atreven, sin embargo, a afirmar que los factores individuales (sensación de control y la calidad de la amistad) ejercen como factores de protección frente a la depresión.

\section{Informe sobre la situación de las personas con disca- pacidad en España}

OBSERVATORIO ESTATAL DE LA DISCAPACIDAD LAS PERSONAS CON DISCAPACIDAD EN

ESPAÑA. INFORME OLIVENZA 2010. OLIVENZA, OBSERVATORIO ESTATAL DE LA

DISCAPACIDAD, 528 PÁGS., 2010.

REF. 191060.

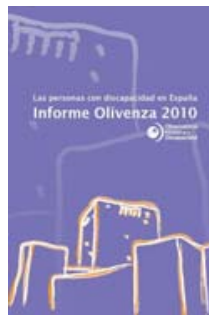

El Observatorio Estatal de la Discapacidad tiene el cometido de impulsar el estudio conjunto de la situación de las personas con discapacidad y de las políticas públicas asociadas. En el contexto de este objetivo, se enmarca esta primera edición del denominado Informe Olivenza, una publicación bienal en la que se recopilan y analizan los principales datos sobre las personas con discapacidad en 
España, trazando una amplia panorámica sobre la evolución reciente de este colectivo.

El informe se estructura en torno a cuatro capítulos monográficos, en los que se abordan a fondo otros tantos aspectos clave: las estimaciones cuantitativas y el perfil sociodemográfico de las personas con discapacidad en España según la Encuesta de Discapacidad, Autonomía Personal y Situaciones de Dependencia (EDAD 2008); la aplicación en España de la Convención Internacional sobre los Derechos de las Personas con Discapacidad; los retos y oportunidades en materia de empleo; y el desarrollo y la aplicación de la Ley de Promoción de la Autonomía Personal y Atención a las Personas en Situación de Dependencia.

Junto al análisis en profundidad de estos cuatro temas, el informe ofrece una selección de indicadores estadísticos que aportan datos de interés sobre diversos ámbitos relevantes (prevalencia, etiología, necesidades educativas especiales, contratación, protección económica, accesibilidad e información relativa al Sistema para la Autonomía y Atención a la Dependencia). Asimismo, incluye una crónica informativa de la discapacidad a lo largo de los años 2008 y 2009 , que se completa con un avance de la actualidad del sector en 2010. investigación

y evaluación

infancia

Sistema de indicadores para niños y adolescentes

OBSERVATORIO DE INFANCIA Y ADOLESCENCIA SISTEMA DE INDICADORES PARA EL

SEGUIMIENTO DE LA REALIDAD DE LA INFANCIA Y LA ADOLESCENCIA EN LA CAPV / EAEKO HAUR ETA NERABEEN ERREALITATEAREN JARRAIPENA EGITEKO ADIERAZLEEN SISTEMA. VITORIA-GASTEIZ, EUSKO JAURLARITZAGOBIERNO VASCO,

188, 189 PÁGS., 2010. REF. 194070. 7

El presente documento recoge un sistema de indicadores sintético que ofrece información actualizada sobre la infancia y adolescencia de la CAPV, la cual permite a la Dirección de Política Familiar y Comunitaria de Gobierno Vasco realizar un seguimiento de la situación de este colectivo, así como ofrece a otros agentes sociales información de interés en esta materia. La metodología empleada para elaborar este trabajo ha consistido en una revisión de documentos y publicaciones que recogen datos cuantitativos vinculados a la infancia y la adolescencia, y en la selección de indicadores clave que fueron convertidos en indicadores operativos. Los indicadores que se presentan en este trabajo están agrupados en los siguientes temas: demografía, familia, salud y sexualidad, educación, recursos económicos y vivienda, ocio y tiempo libre, y entorno e integración.

El interés de esta obra radica en que este sistema de indicadores es una herramienta de trabajo clara, concisa y manejable, que permite realizar un seguimiento del bienestar infantil y evaluar los progresos realizados como vía para la mejora de las políticas en materia de infancia y adolescencia. A este respecto, es importante tener en cuenta que este sistema de indicadores ofrece un panorama general sobre la situación de la infancia y la adolescencia en la CAPV, y no se centra exclusivamente en situaciones de especial vulnerabilidad o exclusión.

\section{investigación \\ y evaluación}

inclusión

\section{Recomendaciones en materia de reinserción de exrreclusos}

JARMAN, B. Y SCURFIELD, L. (EDS.) THE SOCIAL REINTEgRation OF EXPRISONERS IN CoUnCIL OF EURope Member States. Bruselas, QUaker Council for EURopean AfFaIRS, 132 PÁGS., 2011. REF. 195681.

El Consejo Cuáquero de Asuntos Europeos viene publicando, desde hace algunos años, una serie de documentos en los que se abordan las medidas penales y otros programas de intervención dirigidos a las personas que han cometido delitos. La última aportación a dicha serie es este informe que analiza la reintegración social de exrreclusos en Europa. Se trata de un documento que pretende estudiar la situación actual de los programas de reinserción orientados a personas que han cumplido penas de prisión. Para cumplir con este objetivo, se llevó a cabo una encuesta entre los Ministerios de Justicia de los 47 Estados miembros del Consejo de Europa. Los resultados de esa encuesta se presentan junto con otros datos elaborados por el programa de estadísticas penales del Consejo de Europa y por el International Centre for Prison Studies del King's College de Londres.

En los siete capítulos monográficos del documento se analizan los diferentes servicios y programas de reintegración existentes, a saber: los programas de rehabilitación de las drogodependencias; los tratamientos con delincuentes sexuales; los planes educativos; las intervenciones dirigidas a fomentar la integración laboral, económica y de vivienda; los proyectos en los que participan los familiares; $y$, por último, los programas dirigidos a fomentar la participación política de los exrreclusos. Después de esta revisión, el Consejo Cuáquero de Asuntos Europeos constata que los programas de reinserción están infrautilizados.

La entidad señala, por otro lado, que los países europeos deben concienciarse de la importancia de no olvidar los objetivos integradores del sistema judicial. De lo contrario, argumentan, el número de personas exrreclusas no integradas aumentará, lo cual se traducirá en un innecesario incremento del gasto social. En este contexto, señalan los cuáqueros, conviene también recordar que una amplia evidencia científica que demuestra que las penas de prisión no constituyen el mejor método de reinserción. No basta, por lo tanto, con elaborar e implantar programas de reinserción, sino 
que, a largo plazo, se deben ir sustituyendo las penas de cárcel por medidas alternativas capaces de favorecer la integración social y laboral.

\section{Gizartean ematen diren desberdintasunak eta partaidetza}

LANCEE, B. ETA VAN DE WerfHorst, H. InCOME INEQUality AND PARTICIPATION: A Comparison of 24 European Countries / INCOME INEQUALITY AND PARTICIPATION: A Comparison of 24 European Countries. ApPendix. Serie: Gini Discussion Paper, 6. ZENB., AMSTERDAM, GROWING INEQUALITIES' IMPACTS, 41, 21 OR., 2011. ERREF: 192409.

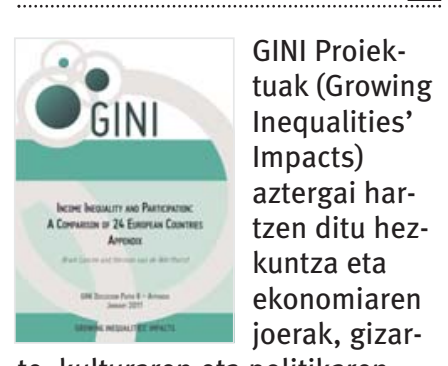

te, kulturaren eta politikaren eraginak gizarte-desberdintasunen mailak neurtzean. Batik bat, azken aroan aztergai hartu izan dituzte diru-sarbideen desberdintasunak, betiere, lotura finkatuz osasunaren eta hezkuntzaren arloetan. Askotariko diziplinak hartzen ditu GINI Proiektuak bere baitan, eta metodologia eta neurrien estandarizazioa ditu helburu hainbat herrialdeetako datuen eta emaitzen arabera eztabaidak eta ikerketak bideratzeko.

Amsterdamgo Unibertsitateak gidaturiko txosten labur honen helburua izan da, gizartearen baitan ematen diren desberdintasunak aintzat harturik, gaiak hiritarren partaidetzan duen eragina ezagutaraztea, Europako 24 herrialderen arteko azterlanean egindako konparatze baten bidez. Testu honetan, desberdintasunaren eta partaidetzaren arteko harreman ezkorra maila teorikoan aztertu dute. Gizartearen berezko prozesuetan, estatusari kontu hartzen diote teoria batzuek. Gainera, desberdintasuna oso nabarmena den lurraldeetan, pobreek ez dute gizartean partaidetzarik izaten, sineskortasun urriagoa dute, eta osasuna eskasagoa izan ohi da populazioaren estratu horretan. Azken batean, diru-sarbide urriak dituzten familietan partaidetza eta boluntariotza ezezaguna izan ohi da, behintzat, diru-sarbide gehiago dutenen kasuen aldean konparatuz; eta urriagoa izaten da partaidetza, oro har, desberdintasun-maila hedatuagoa den herrialdeetan.

\section{atención}

residencial

envejecimiento

\section{Abordaje de las conductas desafiantes en personas con demencia}

JAMES, I. A

UNDERSTANDING BEhAVIOUR IN DEMENTIA that Challenges. A Guide to Assessment AND TREATMENT. LONDRES, JeSSICA KINGSLEY PublisheRS, 176 PÁGS., 2011. REF. 196436.

El envejecimiento demográfico ha traído consigo un marcado incremento de los diagnósticos por demencia, que tienden a

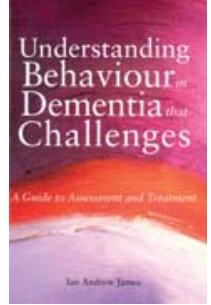

concentrarse en edades avanzadas. Las llamadas conductas desafiantes se detectan en el $90 \%$ de los casos de demencia, y además de repercutir negativamente en la calidad de vida de las personas afectadas y sus familias, pueden llegar a desbordar a los profesionales sociosanitarios, que a veces desconocen el modo más eficaz de responder a estos comportamientos. De ahí el interés de este manual, que analiza el concepto de conducta desafiante en pacientes con demencia, orienta sobre su diagnóstico, y sugiere pautas y modelos de intervención.

Las conductas desafiantes se definen aquí como un constructo social que engloba un amplio abanico de acciones caracterizadas por originar algún tipo de dificultad, bien para la persona con demencia, bien para el entorno donde habita. Sus causas no son solamente neurológicas, sino también físicas y psicosociales. Estudios recientes plantean que este comportamiento 'problemático' puede expresar una necesidad no cubierta, un esfuerzo del individuo por satisfacerla directamente o una frustración. Desde esta pers pectiva, se podrían calificar de conductas adaptativas mediante las cuales la persona trata de sentirse bien, o mitigar su angustia 0 ansiedad.

La discusión teórica se complementa $-y$ en ello reside el principal interés del libro- con propuestas concretas para el abordaje de las conductas desafiantes en personas con demencia. Junto a varios estudios de caso, el autor pone como modelo el servicio especializado de un centro de Newcastle del que es director, al tiempo que propone algunas recomendaciones generales para mejorar este tipo de dispositivos. En sintonía con la complejidad de los cuadros clínicos tratados, James aboga por una intervención exigente en recursos y el énfasis en las técnicas psicosociales. 

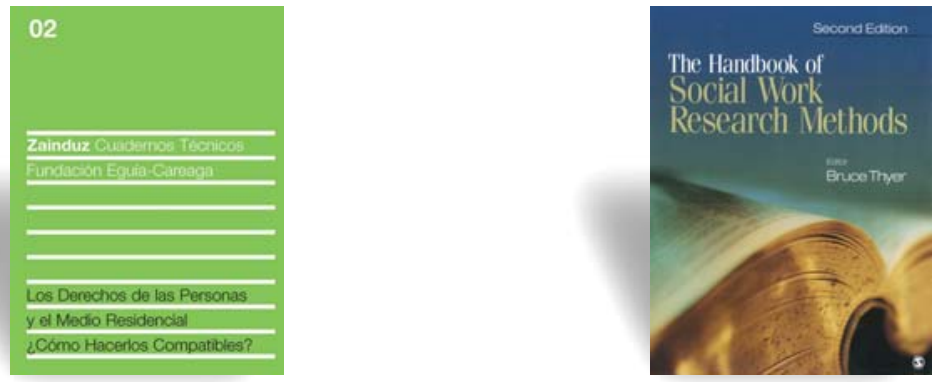

herra ? tas tres
Recomendaciones para equilibrar los derechos individuales y las necesidades organizativas en el ámbito residencial

Este segundo Cuaderno Técnico de la serie Zainduz, realizada por el SIIS-Centro de Documentación y Estudios de la Fundación Eguía-Careaga, propone una serie de recomendaciones prácticas, principios, criterios, ideas y pautas capaces de contribuir a compatibilizar los derechos y las necesidades de las personas mayores que viven en residencias con los imperativos organizativos del medio residencial, atenuando sus contradicciones propias, en particular, la contraposición entre lo individual y lo colectivo, entre la esfera privada y la pública, entre el ámbito residencial como lugar de vida y de trabajo. Al igual que el proceso de garantía de calidad Kalitatea Zainduz (ref. 155683), que se publicó como no 1 de esta serie, esta guía se inscribe en una filosofía que pone el énfasis en el respeto de los derechos de las personas residentes y en los aspectos cualitativos de la atención y, como tal, es deudora del método de evaluación británico Homes Are for Living in, que fue pionero, a escala internacional, en la adopción de este enfoque.

Las recomendaciones contenidas en el cuaderno técnico se han estructurado en torno a siete ámbitos -aspectos materiales, atención personal, forma de vida, relaciones personales dentro de la residencia, relaciones con el exterior, organización y funcionamiento de la residencia, y trabajo en el medio residencial-, indicando, para cada una de las recomendaciones, los derechos individuales básicos en los que puedan incidir. Para facilitar su consulta por parte de los y las profesionales, se ha diseñado también una versión abreviada, con formato de póster. Asimismo, para facilitar su discusión entre residentes y familiares, la guía se complementa con un cuadernillo que ofrece una versión más breve del texto.

SIIS-CENTRO DE DOCUMENTACIÓN Y ESTUDIOS LOS DERECHOS DE LAS PERSONAS Y EL MEDIO RESIDENCIA ¿Cómo hacerlos compatibles? SeRIE: Zainduz Cuadernos TÉCNICOS, No 2. DONOSTIA-SAN SEBASTIÁn, FUndACIÓN Eguía-CareagA, 75 PÁGS., 2011. Ref. 196700.
Gizarte Langintzarako gidaliburu berritua

Hamar urteren ostean, Gizarte Langintzaren inguruan egiten diren azterlanen gidaliburu berritua argitaratu du Ameriketako Estatu Batuetako argitaletxe batek. Izan ere, joandako hamarkadan bultzaturiko zientziak probatan jasotako ebidentziak atzeman nahi izan ditu, eta, oro har, eragina izan du paradigma berri horrek hainbat diziplinetan. Laburki, ikerketa kuantitatibo nahiz kualitatiboetan datuen bilketaren eta ikerketaren alorrean egindako azterlanen ereduak jaso dituzte, eta azkeneko zatian, ikerketen kontzeptuen analisia burutzeaz gain, Gizarte Langintzarako ikerketetan ageri izandako bestelako gai interesgarriak hartu dituzte aztergai liburu mardul honetan.

Gizarte Langintzarako ikerketak burutzerako orduan, hiru alorretako lanabesak azpimarratzen dituzte testuan: aldizkari profesionalak, liburuak eta Internetek eskainitako baliabideak. Horretarako, baliabideak eskaintzen ditu testuak, eguneratutako informazioa eta lanabesak proposatzen dituelarik, betiere, gizarte arloko ikerketak eta praktika hobetzearren. Ikuspegi kuantitatiboari jarraikiz, estatistikaren zentrorako joeraren neurriak (bataz besteko aritmetikoa, moda eta mediana) eta datuen dispertsiorakoak argiro azaltzen dituzte testuan. Izan ere, askotariko zailtasunak izaten dituzte gizarte-langileek horrelako datuak interpretatzerako orduan, eta paradigma berriaren baitan garrantzia handiagoa dute, oraindik ere, testuan jasotako aspektu kuantitatiboek. Azkenik, Gizarte Langintzaren diziplinaren baitan ohikoagoak diren alde kualitatiboak aztertu dituzte testuan, eta jaso egin dituzte kasu kliniko eta ahozko historien kasu partikularrak.

THYER, B. (ED.)

The Handbook of Social Work Research Methods (2 ${ }^{\text {ND }}$ Edition). Londres, Sage Publications, 654 OR., 2010. ERREF.: 188457. 
Programa de intervención cognitiva integral en pacientes con demencia

El Centro de Referencia Estatal de Atención a Personas con Enfermedad de Alzheimer y otras Demencias (CRE Alzheimer Salamanca), dependiente del Imserso, ha elaborado el presente Programa de Actuación Cognitiva Integral en Demencias (PACID). Se trata de un programa de estimulación cognitiva integral, dirigido específicamente a la intervención en demencias, que tiene por objetivos preservar las funciones cognitivas dentro del proceso de deterioro, prevenir los problemas de conducta, mejorar el estado funcional y favorecer la implantación de programas de apoyo psicoeducativo.

Las demencias, en general, y la enfermedad de Alzheimer, en particular, constituyen trastornos neurodegenerativos irreversibles que ocasionan un deterioro global persistente y que conllevan, por consiguiente, un grave deterioro de la vida cotidiana de la persona afectada y de su entorno. Sin embargo, la progresión de estos procesos degenerativos es heterogénea, por lo que los procesos de evaluación y las consecuentes intervenciones que se planifiquen con estos pacientes deberán ser lo suficientemente flexibles para amoldarse a las características de cada persona afectada. En esta línea, el PACID se presenta como un programa basado en la adaptación individual a las necesidades de los pacientes, multidimensional, abierto, interactivo, autoevaluable y gratuito. El programa se desarrolla a lo largo de nueve meses, de los cuales seis son de intervención directa y tres de evaluación. El presente documento expone de modo sintética los fundamentos teóricos del PACID, sus áreas de intervención, la secuenciación de sus contenidos, los recursos que utiliza, y los criterios de gestión y evaluación.

GARCía, J. J. ET AL.

Programa de Actuación Cognitiva Integral en

Demencias (PACID): Centro de Referencia Estatal de

Atención a Personas con Enfermedad de Alzheimer y OTRAS DEMENCIAS. EL TREN DE LA INTERVENCIÓN COGNITIVA. MADRID, MINISTERIO de SANIDAD Y PolítICA SOCIAL, 72 PÁGS., 2011. REF. 195377.
Proyectos dirigidos a personas prostituidas

Desde siempre se ha considerado que las personas que ejercen la prostitución en clubes y pisos son más vulnerables que las que 'hacen la calle'. No obstante, también están expuestas a riesgos. Se trata, además, de un colectivo 'aislado', difícil de alcanzar para los profesionales que intentan mejorar sus condiciones de trabajo y su calidad de vida. Teniendo en cuenta que el número de trabajadores del sexo que ejercen la prostitución bajo techo, debido a recientes reformas legislativas y al uso de las nuevas tecnologías, está en aumento, resulta evidente la necesidad de diseñar nuevos servicios y estrategias para atender sus necesidades. Por ello, en 2008 seis organizaciones de cinco países europeos decidieron poner en marcha Indoors, un proyecto cuyo principal objetivo es establecer una serie de recomendaciones para elaborar programas dirigidos a este colectivo. Este documento, que recoge los resultados de ese trabajo, dedica los capítulos iniciales a revisar los conocimientos actuales sobre las condiciones en las que viven y trabajan las personas prostituidas. Muchos de los datos presentados tienen su origen en una encuesta realizada entre cerca de dos mil personas que ejercen la prostitución en siete ciudades europeas (Génova, Hamburgo, Marsella, Nantes, Oporto, Sofía y Trieste). La segunda parte del libro reúne una serie de buenas prácticas de muy diversa índole, entre las que destacan el uso de taxistas y personal de sex shops como intermediarios, la creación de foros y blogs para el intercambio de información, así como la puesta en marcha de servicios médicos móviles.

FAVET, L. ET AL. (EDS.)

Indoor Sex Work. Analysis and Good Practice Manual on Indoor Sex Work Settings in Seven European Cities. MARSELLA, Autres REgARDS, 118 PÁGS., 2010. REF. 194446.
Manual de acogimiento familiar

El acogimiento familiar es una alternativa de acogida para aquellos niños y niñas que tienen que vivir separados de sus familias, pero en un ambiente familiar adecuado a sus necesidades. La futura Ley de Protección de la Infancia, que en la actualidad está en desarrollo y cuyo principal objetivo es simplificar y mejorar los mecanismos de acogida y adopción, va a potenciar el acogimiento familiar de menores en situación de desamparo, frente al ingreso en centros residenciales. El presente manual sobre el programa de acogimiento familiar ha sido elaborado por Pere Amorós, catedrático de la Universidad de Barcelona y reconocido experto en la materia, y publicado por la Dirección General de Políticas Sociales y el Instituto Cántabro de Servicios Sociales (ICASS). Su principal objetivo es ofrecer a profesionales $y$ responsables del sistema público de protección a la infancia unos procedimientos y unos instrumentos que faciliten su intervención sobre bases sólidas y seguras. De manera específica, esta guía busca dar respuesta al desarrollo de una práctica profesional alrededor de la toma de decisiones, la salida del niño o la niña de su hogar para entrar en otro, la disponibilidad y la preparación de familias de acogida, el trabajo con los padres de cara a su recuperación y con los acogedores de cara a que el acogimiento trascurra en la mejores condiciones. En la parte final del libro, se presentan un interesante listado de indicadores de valoración para el acogimiento en familia extensa y tres instrumentos de valoración - del niño/a, de la familia ajena y de la familia extensa-.

AMORós, P.

Procedimiento Y CRITERIOS DE ACtUACIÓN DE LOS

PROgRAMAS de ACOGIMIENTO familiar. SERIE: MANUAL CANTABRIA, № 9. SANTANDER, GobieRno de CANTABRIA, 103 PÁGS., 2011. REF. 194080. 

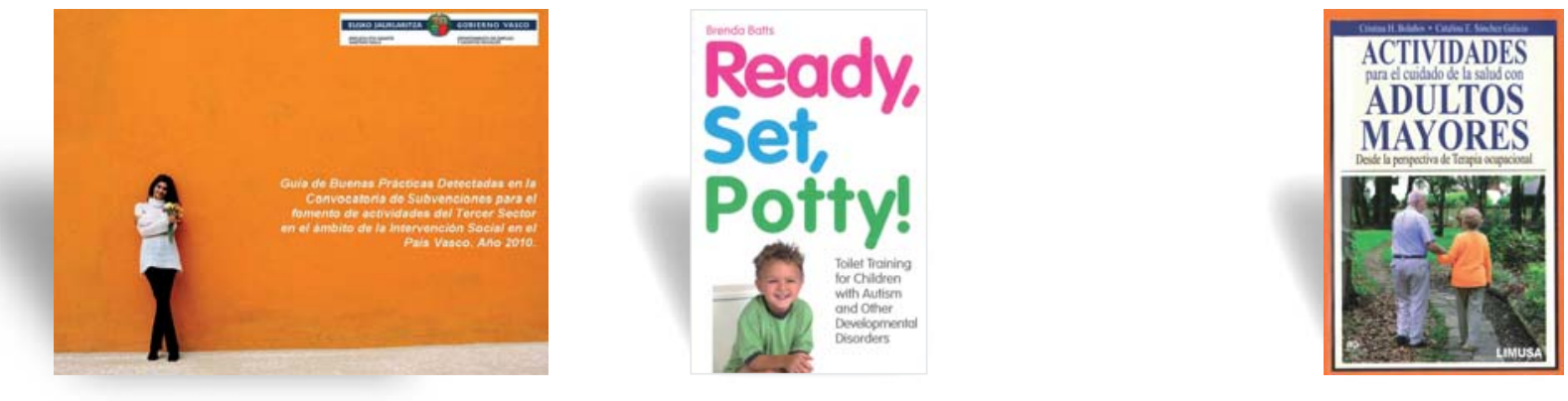

Buenas prácticas de intervención social del tercer sector en Euskadi

La financiación pública permite a muchas entidades del tercer sector llevar a cabo sus proyectos sociales. Sin embargo, elaborar un buen proyecto no basta para obtener el apoyo económico de las administraciones públicas: es preciso, además, que encaje en las prioridades que las autoridades establezcan en cada momento. Con el ánimo de facilitar ideas y elementos de mejora a las entidades que quieran presentarse a la convocatoria de Subvenciones para el Fomento de Actividades del Tercer Sector en el Ámbito de la Intervención Social en la CAPV, el Gobierno Vasco ha editado esta guía, que recoge 29 proyectos beneficiarios de las ayudas de 2010.

Como criterio de selección, se ha empleado, junto con la calidad global del proyecto, el hecho de que se trate de iniciativas especialmente completas y equilibradas, dado que presentan un carácter integral, medidas especializadas o individualizadas de intervención, un amplio alcance, una elevada evaluabilidad y trazabilidad, así como una gran coherencia interna. Igualmente, se han valorado elementos tales como la innovación social, la imbricación de las perspectivas medioambiental y de género, la eficacia y la coordinación a escala supraterritorial, y la creación de espacios transversales (sociosanitarios, socioculturales, socioeducativos). Los proyectos reunidos abarcan las tres líneas cubiertas por la convocatoria: intervención social con familias grupos y comunidades; fortalecimiento de la acción voluntaria y la participación asociativa en la intervención social; y gestión del conocimiento para la intervención social.

Departamento de EMPLEO Y Asuntos Sociales GUÍA dE BUENAS PRÁcticas DETECTADAS EN LA CONVOCATORIA DE SUBVENCIONES PARA EL FOMENTO DE ACTIVIDADES DEL TERCER SECTOR EN EL ÁMBITO DE LA INTERVENCIÓN SOCIAL EN el País Vasco. AÑo 2010 / Euskal Autonomia ERKidegoko ESKU-HARTZE SOZIALAREN EREMUAN HIRUGARREN SEKTOREKO JARDUERAK SUSTATZEKO DIRU-LAGUNTZA DEIALDIAN JARDUERAK SUSTATZEKO DIRU-LAGUNTZA DEIALDIAN
HAUTEMANDAKO PRAKTIKA ONEN GIDA. 2010 URTEA. VITORIAGASTEIZ, EUSKO JAURLARITZA-GOBIERNO VASCO, 36 PÁGS., 2011. REF. 196375.
Manual para enseñar a niños autistas a usar el orinal tirse en un proceso estresante para cualquier niño, pero para los menores con autismo puede constituir un auténtico reto. Las dificultades especiales que tienen estos niños para dejar los pañales vienen originadas por varios factores. Como regla general, se puede decir que a los niños autistas les resulta complicado captar conceptos nuevos, y éste es el caso también del entrenamiento para controlar los esfínteres. Les cuesta, en primer lugar, adquirir las habilidades prácticas necesarias para hacer uso del orinal o el inodoro, y una vez que las posean, les resulta, a menudo, difícil aplicar esas aptitudes en ambientes diferentes al que sirvió de escenario para el aprendizaje. Pensando en las necesidades de las personas adultas implicadas en este proceso de aprendizaje, la consultora de conducta Brenda Batts, madre de un hijo autista, ha elaborado este documento que explica cómo abordar el problema de manera eficiente. No se trata de un modelo único que debe servir para todo el mundo, sino más bien un recopilatorio de buenas prácticas. La idea es que los padres y los profesionales, con la ayuda de estos consejos, puedan diseñar un programa adaptado a las necesidades individuales del niño al que están atendiendo. El libro presenta también una recopilación de casos que, entre otras cosas, sirve para demostrar que no hay situaciones imposibles. Brenda Bratts ha creado un recurso único en su tipo, en el que se enseña que, aunque el entrenamiento para abandonar el pañal no es ningún juego de niños, y tampoco ha de tratarse como tal, no tiene por qué suponer un trauma para el pequeño y no ha de ser agotador para el adulto que le acompaña en el aprendizaje.

\section{BATTS, B.}

Ready, Set, Potty! Tollet Training for Children with AUtISM AND OTHER DEVELOPMENTAL DISORDERS. LONDRES, JeSSICA KINGSLEY PUblishers, 144 PÁGS., 2010. REF. 189857.
Aprender a utilizar el orinal tiende a conver-
Guía de actividades de terapia ocupacional en la atención a personas mayores

La sociedad está en un constante cambio y, con ella, la consideración social de las personas mayores y su propia percepción como individuos con capacidad de estar en el mundo: cada vez más, los mayores quieren mantenerse informados, participativos y activos. La terapia ocupacional es buen recurso en este sentido, puesto que se basa en la idea de que la ocupación del tiempo puede promover la salud y el bienestar de la persona, entendiendo las ocupaciones como tareas organizadas con valor y significado para el individuo y su cultura. La presente guía está dirigida a orientar la organización de los programas de actividades de las diversas instituciones, y es un buen manual para conocer los mejores modos de desarrollar la terapia ocupacional. Dividida en cuatro capítulos, el primero analiza las necesidades y la situación de las personas mayores, y señala nuevos retos y oportunidades en este ámbito. En el segundo capítulo, se habla de cuestiones cotidianas que afectan a las personas mayores y que tienen que trabajar, como el mantenimiento de la flexibilidad y la movilidad, la psicomotricidad o la toma de medicamentos. El capítulo tres se refiere a la organización de los programas de actividades, y analiza paso a paso todas las cuestiones que deben tenerse en cuenta a la hora de planificar una actividad desde la perspectiva de la terapia ocupacional. Por último, el cuarto capítulo -el más extenso de la guía- es un completo catálogo de actividades, dividido en tres secciones independientes (actividades de cuidado y desarrollo personal, actividades de creatividad, y actividades de esparcimiento y recreativas), con esquemas e imágenes detalladas que facilitan su lectura y comprensión.
Bolaños, C. H. Y SÁNCHEZ, C. E.

ACTIVIDADES PARA EL CUIDAdO DE LA SALUd CON ADULTOS MAYORES DESDE LA PERSPECTIVA DE TERAPIA OCUPACIONAL. MÉXICO D.F., LIMUSA, 284 PÁGS., 2010. REF. 193463. 


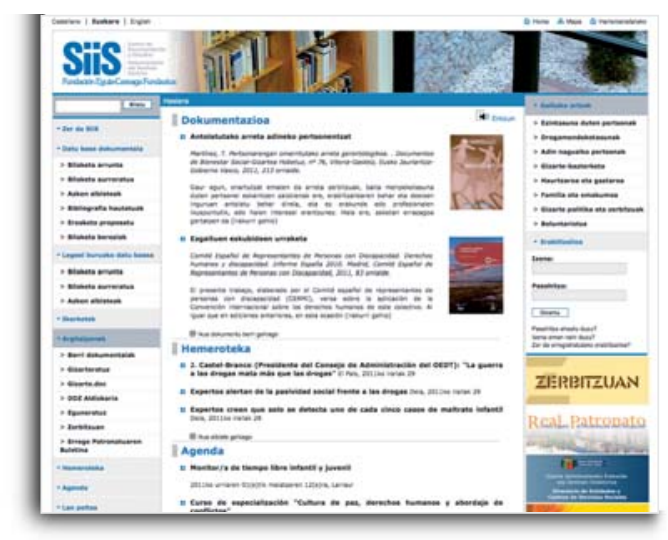

\section{WWW}

\section{Nuevos servicios y productos en la página electrónica} www.siis.net

A lo largo de 2011, se ha mejorado el acceso a los servicios y productos documentales que se prestan a través de la página electrónica del SIIS Centro de Documentación y Estudios. Se describen a continuación las principales características de estas mejoras:

\section{Nuevo visor para las publicaciones}

Las publicaciones que elabora el SIIS (Gizarteratuz, Boletín CDD, Boletín del Real Patronato, así como la revista Zerbitzuan) se pueden visualizar a partir de ahora mediante el visor Issuu, lo que permite una lectura más ágil en pantalla, sin necesidad de imprimir el documento en cuestión. Se mantiene, no obstante, la posibilidad de descargar el documento el pdf.

\section{Sistema de audiolectura} Complementariamente, se ha instalado un programa de audiolectura de contenidos, que permite escuchar todos los documentos en pdf colgados en el servidor del SIIS, desde las citadas publicaciones hasta las noticias de prensa o las normas legislativas.
SIISek eguneratutako lotura eta esteka interesgarri propioak kudeatzen ditu Delicious izeneko gunearen helbide honetan: <www.delicious.com/siisnet>. Gizartearen alorrean lan egiten duten Estatuko zein nazioarteko erakundeen eta baliabideen berr aurkituko duzu bertan.

El SIIS gestiona y actualiza una base de datos de enlaces propia en Delicious, consultable en $<w w w . d e l i c i o u s . c o m / s i i s n e t>$. Se trata de una selección de enlaces a entidades y recursos de interés en el ámbito de lo social, tanto a escala estatal como internacional.

\section{Servicio de búsquedas personalizadas y} alertas periódicas

(«www.siis.net/es/busquedaspersonalizadas.php»)

Mediante un formulario específico, se puede solicitar al personal del SIIS que realice una búsqueda concreta en sus bases de datos. La persona usuaria puede solicitar asimismo que se le informe periódicamente de las novedades bibliográficas que se van recibiendo en el centro de documentación sobre los temas de su interés.

\section{Listados}

bibliográficos temáticos

(«www.siis.net/es/bibliografia s-tematicas.php $)$

Se trata de selecciones documentales sobre temas especialmente interesantes (atención centrada en la persona, rentas mínimas y activación, uso de restricciones físicas, financiación de la dependencia, por ejemplo). Estos listados, que se actualizan periódicamente, otorgan prioridad a los documentos de acceso completo en línea y en castellano, aunque incluye lógicamente los documentos más relevantes en otros idiomas.

\section{Últimas novedades del fondo} («www.siis.net/es/ultimasnovedades-

documentales.htm(»)

Esta sección permite a las personas que consultan la página electrónica acceder directamente a todas las últimas novedades incorporadas a las bases de datos, tanto documental como legislativa, en cada uno de los colectivos de interés.

\section{Sugerencias de compra} («www.siis.net/es/sugerircompra.php〉)

Mediante un formulario, la persona usuaria puede solicitar la adquisición e introducción en la base bibliográfica de documentos de especial interés.

Valoración de documentos Los usuarios tienen la posibilidad de puntuar los documentos de la base de datos del SIIS, así como de introducir comentarios sobre ellos. Igualmente, se pueden leer las valoraciones realizadas por otros usuarios, 0 enviar por correo electrónico la referencia del documento a otra persona.

\section{Lectura recomendada}

Esta sección permite acceder a documentos de gran interés cuya lectura se considera especialmente recomendable. Se trata de documentos destacados en cada uno de los ámbitos temáticos de la página electrónica, fundamentalmente en castellano y accesibles a texto completo en línea.

Esperamos que estas mejoras resulten de interés para las personas usuarias de los servicios y productos del SIIS Centro de Documentación y Estudios. En todo caso, animamos a cualquier persona interesada a que nos haga llegar sus sugerencias y comentarios a 〈documentacion@siis.net〉. 


\section{agen
deial diak}

\section{Urria Octubre}

Jornada "Presente y futuro de la infancia y adolescencia vasca: un reto común"

Vitoria-Gasteiz, 19 de octubre. Organiza: Departamento de Empleo y Asuntos Sociales del Gobierno Vasco. Más información:

Tel.: 945122293.

www.inscripcionweb.net/infanciayadolescencia/

irene@fideliza.es

III Jornadas sobre Salud Mental y los DD.HH.: "Miradas hacia los derechos humanos"

Bilbao, 20 a 22 de octubre. Organiza: Asociación Vasca de Salud Mental y Psiquiatría Comunitaria. Más información: Fax: 944573689. www.ome-aen.org jornadasddhh@ome-aen.org

Jornada "Trastornos psicológicos y de conducta en personas con demencia institucionalizadas" Donostia-San Sebastián, 21 de octubre. Organiza: Matia Innova. Más información:

Tel.: 943224143 .

www.matiainnova.com

netxaniz@matiainnova.com

15a Edición del Salón de Ocio, Servicios y Actividades para los Mayores, "Nagusi 2011"

Bilbao, 21 a 23 de octubre. Organiza: Bilbao Exhibition Centre. Más información: Tel.: 944040094 . www.bilbaoexhibitionscentre.com nagusi@bec.eu

XXXII Congreso Nacional de Terapia Familiar: "Adolescencia y terapia familiar"

Bilbao, 27 a 29 de octubre. Organiza: Asociación Vasco-Navarra de Terapia Familiar. Más información: Tel.: 944757880 .

congresoadolescenciayterapiafamiliarfeatf2011.es congresofeatf2011@avntf-evntf.com
Los derechos de las personas mayores y la prevención del trato inadecuado

Vitoria-Gasteiz, 27 y 28 de octubre; y Bilbao, 24 y 25 de noviembre. Organiza: Matia Innova. Más información: Tel.: 943224143.

www.matiainnova.com netxaniz@matiainnova.com

\section{Azaroa Noviembre}

International Conference "Ageing Globally-Ageing Locally"

Dublín, 2 y 3 de noviembre. Organiza: Centre for Ageing Research and Development in Ireland (CARDI).

Más información:

Tel.: +44 (0)2890690066.

www.cardi.ie

conference@cardi.ie

$2^{\text {nd }}$ International Workshop on the Socio-Economics of Ageing Lisboa, 4 de noviembre. Organiza: Paula Albuquerque y Francisco Nunes. Más información: Tel.: +351213951787. pascal.iseg.utl.pt

\section{Congreso Nacional SEMER:}

"Calidad de vida"

Almería, 3 a 5 de noviembre. Organiza: Sociedad Española de Médicos de Residencias (SEMER). Más información: Tel.: 915532200.

www.semer.es

semer@semer.es

Conference "Volunteering as a means to fight social exclusion in Europe today"

Bruselas, 7 y 8 de noviembre. Organiza: Ecumenical Diaconal Year Network (EDYN) y Eurodiaconia. Más información: Tel.: +32 22343860 . www.eurodiaconia.org office@eurodiaconia.org

Jornada "Trastornos del comportamiento: valoración y abordaje"

Donostia-San Sebastián, 11 de noviembre. Organiza: Matia Innova. Más información:

Tel.: 943224143 .

www.matiainnova.com netxaniz@matiainnova.com
XV Encuentro Internacional de Investigación en Cuidados Madrid, 15 a 18 de noviembre. Organiza: Instituto de Salud Carlos III. Más información: Tel.: 918222546. encuentros.isciii.es congresoinvesten@isciii.es

Jornadas Técnicas Anuales de Mayores 2011: “Centros jóvenes para los nuevos mayores: envejecimiento activo para todos" Madrid, 16 a 18 de noviembre. Organiza: Ayuntamiento de Madrid. Más información:

Tel.: 915496495 . www.viajesniagara.com jornadasmayores2011@viajesniagara.com

Curso "Programa de estimulación cognitiva para personas con demencia avanzada basado en el Método Montessori"

Vitoria-Gasteiz, 17 de noviembre. Organiza: Matia Innova. Más información: Tel.: 943224143 . www.matiainnova.com netxaniz@matiainnova.com

Foro Europeo de Empleo Bruselas, 22 y 23 de noviembre. Organiza: Summit Events Ltd. Más información: +442078282278. www.employmentweek.com anne.kellitt@summit-events.com

Curso "Aprender a usar el Dementia Care Mapping (DCM): nivel básico"

Donostia-San Sebastián, 22 a 25 de noviembre. Organiza: Alzheimer Catalunya Fundació, Bradford Dementia Group y Matia Innova.

Más información:

Tel.: 943224143.

www.matiainnova.com

netxaniz@matiainnova.com 
III Congreso de la Red Española de Políticas Sociales (REPS): "LoS actores de las políticas sociales en un contexto de transformación" Pamplona, 24 a 26 de noviembre. Organiza: Red Española de Políticas Sociales (REPS). Más información: www.espanet-spain.net

Curso "La sexualidad de las personas con discapacidad intelectual"

Bilbao, 25 y 26 de noviembre. Organiza: Bolunta. Más información:

Tel.: 944161511.

www.bolunta.org

bolunta@bolunta.org

Jornada sobre Seguridad Legal en

Residencias: "Desatar al anciano y

al enfermo de Alzheimer"

Madrid, 29 de noviembre. Organi-

za: Confederación Española de

Organizaciones de Mayores

(CEOMA). Más información:

Tel.: 915734998.

www.ceoma.org

Jornadas Internacionales

"Innovaciones en residencias para personas en situación de dependencia: diseño

arquitectónico y modelo de atención"

Madrid, 30 de noviembre y 1 de diciembre. Organiza: Fundación Caser para la Dependencia. Más

información: Tel.: 912146569. www.fundacioncaser.es

Eurochild's $8^{\text {th }}$ Annual Conference: "Tackling Child Poverty through Supporting and Strengthening Families"

Cardiff (Reino Unido), 30 de noviembre a 2 de diciembre. Orga niza: Eurochild. Más información: Tel.: +32 25117083 .

www.eurochild.org

info@eurochild.org

\section{Abendua Diciembre}

International Conference

"Changing Images of Ageing-

International Perspectives for a

Future-Oriented Policy on Senior

Citizens and Generations"

Berlín, 12 de diciembre. Organiza:

German Federal Ministry for Family

Affairs, Senior Citizens, Women and

Youth. Más información:

geschaeftsstelle-altenberichte@dza. de

Curso "Gestor de programas

intergeneracionales"

Donostia-San Sebastián, 16 y 17 de diciembre. Organiza: Matia Innova.

Más información:

Tel.: 943224143 .

www.matiainnova.com

netxaniz@matiainnova.com

\section{2}

\section{Urtarrila Enero}

Curso "La realidad de las personas presas"

Bilbao, 17 de enero. Organiza:

Bolunta. Más información:

Tel.: 944161511.

www.bolunta.org

bolunta@bolunta.org

4ํㅡㄹ Congreso Internacional

REIACTIS: "El derecho a envejecer:

ciudadanía, integración social y

participación política de las

personas mayores"

Dijon (Francia), 25 a 27 de enero.

Organiza: Réseau International

d'Étude sur l'Age, la Citoyenneté et

l'Intégration Socio-économique

(REIACTIS) y Pôle de Gérontologie

Interrégional Bourgogne/Franche-

Comté. Más información:

www.reiactis.org

secretariat.prgi@gmail.com

\section{Otsaila Febrero}

Curso "Manejo de situaciones difíciles con personas mayores dependientes"

Bilbao, 7 a 23 de febrero. Organiza: Bolunta. Más información:

Tel.: 944161511.

www.bolunta.org

bolunta@bolunta.org

\section{Martxoa Marzo}

International Congress on

Telehealth and Telecare

Londres, 6 a 8 de marzo. Organiza:

King's Fund. Más información:

www.kingsfund.org.uk

enquiry@kingsfund.org.uk

VIII Jornadas Científicas de

Investigación sobre Personas con

Discapacidad

Salamanca, 14 a 16 de marzo. Organiza: Instituto Universitario de Integración en la Comunidad de la Universidad de Salamanca (INICO).

\section{Más información:}

Tel.: 923294500.

inico.usal.es

jornadas2012@usal.es

Curso "Intervención socioeducativa con personas privadas de libertad" Bilbao, 23 y 24 de marzo. Organiza: Bolunta. Más información

Tel.: 944161511.

www.bolunta.org

bolunta@bolunta.org

\section{Apirila Abril}

$5^{\text {th }}$ International School Social

Work Conference

Accra, 10 a 13 de abril. Organiza:

School Social Work Association of

Ghana. Más información:

www.sswaghana.org sswconference@yahoo.com
VII Congreso Migraciones Internacionales en España Bilbao, 11 a 13 de abril. Organiza: Universidad del País Vasco, en colaboración con Ikuspegiak Observatorio de Inmigración.

Más información:

www.congresomigraciones2012.com info@congresomigraciones2012.com

\section{Maiatza Mayo}

Curso "Diseño de proyectos sociales desde la perspectiva de género"

Bilbao, 7 a 21 de mayo. Organiza: Fundación EDE. Más información:

Tel.: 944009999.

www.bolunta.org

bolunta@bolunta.org

International Federation on Ageing $11^{\text {th }}$ Global Conference on Ageing:

"Ageing Connects"

Praga, 28 de mayo a 1 de junio.

Organiza: International Federation on Ageing. Más información: www.ifa2012.com

jbarratt@ifa-fiv.org

\section{Ekaina Junio}

$2^{\text {nd }}$ International Congress on Controversies in Longevity, Health and Aging (CoLONGY)

Barcelona, 21 a 24 de junio. Organiza: Comtecmed Medical Congresses. Más información:

Tel.: 932081145 . www.comtecmed.com spain@comtecmed.com 


\section{gizarteratuz 20}

Edukiak/Contenidos SIIS Centro de Documentación y Estudios SIIS Dokumentazio eta Ikerketa Zentroa Fundación Eguía-Careaga Fundazioa

General Etxague, 10 20003 Donostia Fax 9432950 (1) ax 943293007 publicaciones@s.sis.net

publicaciones@sils.ne

(c) Eusko Jaurlaritzako Enplegu C Departamento de Empleo y Asuntos Sociales del Gobierno Vasco

Argitalpena/Edita Eusko Jaurlaritzaren Argitalpen Zerbitzu Nagusia Servicio Central de Publicaciones
del Gobierno Vasco

Donostia-San Sebastián, 01010 Vitoria-Gasteiz

Diseinua/Diseño Estudio Lanzagorta Maketazioa/Maquetación
Concetta Probanza Inprimaketa/Impresión mccgraphics ENPLEGU ETA GIZARTE

ETAKO SAILA

DEPARTAMENTO DE EMPLEO

Y ASUNTOS SOCIALES

Eusko Jaurlaritzaren Argitalpen Zerbitzu Nagusia 